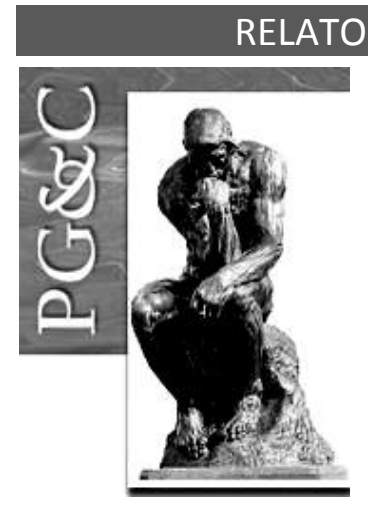

\title{
COMPETÊNCIA EM INFORMAÇÃO E ÉTICA: ESTUDO BIBLIOGRÁFICO ENTRE 2011 E 2015
}

\author{
Eliane Pellegrini \\ Mestranda em Ciência da Informação pela Universidade Federal de Santa \\ Catariana, Brasil. \\ E-mail: elianepellegrini@gmail.com \\ Elizete Vieira Vitorino \\ Doutora em Engenharia de Produção pela Universidade Federal de Santa \\ Catarina, Brasil. Professora da Universidade Federal de \\ Santa Catarina, Brasil. \\ E-mail: elizete.vitorino@ufsc.br
}

\begin{abstract}
Resumo
O objetivo deste estudo é identificar a produção científica sobre competência em informação e as abordagens da ética no âmbito desta competência. Trata-se de uma pesquisa bibliográfica, exploratória e descritiva. Investigou-se nas bases de dados Library and Information Science Abstracts (LISA), Scopus, Education Resources Information Center (ERIC), Web of Science (WoS) e nos periódicos brasileiros da área de Ciência da Informação e Biblioteconomia os artigos científicos publicados no período de 2011 a 2015 sobre competência em informação e que contivessem alguma menção à ética. Foram recuperados 86 artigos científicos nas bases de dados internacionais e 34 nos periódicos brasileiros. A ética aparece, principalmente, vinculada à competência em informação em iniciativas voltadas para a avaliação dos programas e dos níveis de competência em informação dos estudantes, além de inserida nos conceitos desta competência. Há também estudos voltados para as dimensões da competência em informação que citam a ética, e outros que apontam para a importância do uso ético e legal da informação nas profissões e pelos estudantes. Parece haver um consenso dos autores sobre a existência de importante relação entre estas temáticas.
\end{abstract}

Palavras-chave: Competência em informação. Ética. Dimensão ética da competência em informação.

\section{INFORMATION LITERACY AND ETHICS: BIBLIOGRAPHIC STUDY BETWEEN 2011 AND 2015}

\begin{abstract}
This study aims to identify the scientific production on Information Literacy and ethical approaches within this competency. This paper is a bibliographical, exploratory and descriptive research. The investigation was on the databases Library and Information Science Abstracts (LISA), Scopus, Education Resources Information enter (ERIC), Web of Science (WoS) and Brazilian journals of Information and Library Science on scientific articles published from 2011 to 2015 about Information Literacy which had any mention of ethics. There were recovered 86 scientific articles in international databases and 34 in Brazilian journals. Ethics appears mainly on Information Literacy linked to initiatives for evaluation of programs and on the level of students Information Literacy, as well as, set on these competence concepts. There are also studies aimed at the dimensions of the Information Literacy mentioning ethics and others indicate the importance of ethical and legal use of information in the professions and students. There seems to be a consensus from the authors about the existence of significant relationship between these themes.
\end{abstract}

Keywords: Information literacy. Ethics. Ethical Dimension of Information Literacy.

Perspectivas em Gestão \& Conhecimento, João Pessoa, v. 6, n. 2, p. 225-249, jul./dez. 2016. http://periodicos.ufpb.br/ojs2/index.php/pgc. ISSN: 2236-417X. Publicação sob Licença (cc) EY-NC-ND 


\section{INTRODUÇÃO}

Sabe-se que, em âmbito internacional, as primeiras publicações sobre competência em informação surgiram na década de 70, e em âmbito nacional, no início de 2000. Estudos sobre competência em informação se mostram indispensáveis ao pleno desenvolvimento econômico e social dos países, conforme observa-se na Declaração de Alexandria sobre competência em informação e aprendizado ao longo da vida, documento sob a responsabilidade da International Federation of Library Associations and Institutions (IFLA) (2005), e no documento Towards Information Literacy Indicators, organizado por Catts e Lau (2008), publicado pela Organização das Nações Unidas para a Educação, a Ciência e a Cultura (UNESCO).

Identificar e caracterizar a produção científica da área possibilita uma visualização das principais publicações sobre a temática deste campo científico, e propicia um mapeamento do saber construído num dado período de tempo, bem como o monitoramento do desenvolvimento em termos de pesquisas na área (SCHWEITZER; RODRIGUES, 2013). Sob esta perspectiva, os artigos científicos são o principal meio formal da comunicação, e, portanto, o conjunto de revistas científicas produzidas em um país pode ser indicador do estágio do desenvolvimento da ciência nesse cenário (MUELLER, 2011). Na área da competência em informação, não poderia ser diferente.

Assim, e para os propósitos deste trabalho, fez-se um levantamento dos artigos científicos publicados sobre competência em informação no período de janeiro de 2011 a setembro de 2015 em bases internacionais e nos periódicos brasileiros da área de Ciência da Informação e Biblioteconomia, com objetivo de identificar a produção científica sobre competência em informação e as abordagens da ética no âmbito desta competência.

0 referencial teórico a seguir baseia-se no estudo bibliográfico realizado. 0 item seguinte, denominado "resultados", fornece a visualização por meio de quadros e de gráficos do quantitativo de artigos científicos localizados nas bases de dados e nos periódicos científicos.

\section{REFERENCIAL TEÓRICO}

Nos últimos cinco anos, observa-se a ética inserida no contexto da competência em informação de variadas formas.

Os estudos de Orelo e Vitorino (2012) e Vitorino e Piantola (2011), de forma geral, tratam das dimensões da competência em informação. O estudo intitulado "Dimensões da competência informacional" de Vitorino e Piantola (2011) reflete acerca das quatro dimensões da competência em informação - técnica, estética, ética e política - com foco em aspectos educacionais e filosóficos. O estudo das dimensões da competência em informação se dá a partir do marco teórico de Rios (2010) e com base em pesquisas já iniciadas e publicadas. Com relação a ética no contexto da competência em informação, as autoras afirmam que "o indivíduo que é efetivamente competente em informação é capaz de tomar posição, assumir uma postura crítica diante de determinadas informações, o que requer, na maioria das vezes, um julgamento de valor" (VITORINO; PIANTOLA, 2011, p. 105). Além disso, "praticar o comportamento ético em relação à informação significa ainda utilizá-la de modo responsável, sob a perspectiva da realização do bem comum" (VITORINO; PIANTOLA, 2011, p. 106).

No artigo "Competência informacional: um olhar para a dimensão estética", Orelo e Vitorino (2012, p. 41) observam que "ser competente em informação significa desenvolver um conjunto de habilidades para o uso eficiente dos recursos informacionais, o aprendizado ao longo da vida e o pensamento crítico". As autoras defendem que a competência em informação precisa fundar-se em quatro dimensões a fim de desenvolver-se com plenitude:

Perspectivas em Gestão \& Conhecimento, João Pessoa, v. 6, n. 2, p. 225-249, jul./dez. 2016. 
técnica, estética, ética e política. Entretanto, neste estudo enfatizam a dimensão estética e suas contribuições para a Sociedade da Informação. Com relação a dimensão ética, brevemente abordada, afirmam que se trata daquela que determina o que o indivíduo pode ou não fazer considerando os valores sociais.

Chang et al. (2012), no estudo intitulado Assessing students information literacy skills in two secondary schools in Singapore, defende a necessidade de medir adequadamente o nível de competência em informação dos estudantes a fim de compreender seu impacto educacional. Para isso, descreve um instrumento de coleta de dados que inclui uma nova dimensão do uso ético da informação, bem como os princípios e diretrizes da competência em informação. Para estes autores, a investigação sobre o comportamento dos estudantes na busca de informação contribui para a compreensão de novas dimensões da competência em informação, considerando fatores do contexto social, mas não limitando a cultura, as normas sociais, hábitos, práticas, expectativas, recompensas e preferências do grupo que um indivíduo pertence.

$\mathrm{O}$ artigo Information literacy skills of secondary school students in Singapore, de Foo et al. (2014), objetivou analisar as habilidades de busca, avaliação e utilização da informação dos estudantes do ensino secundário de escolas em Singapura. O instrumento de coleta de dados consistiu em um questionário desenvolvido por membros do corpo docente da Nanyang Technological University (NTU), em Singapura, e incluiu uma dimensão do uso ético da informação. Algumas questões contidas no instrumento objetivam testar o conhecimento dos alunos sobre ética da informação.

Noutro artigo, intitulado Overcoming time and ethical constraints in the qualitative data collection process: a case of information literacy research, de Yu, Abdullah e Saat (2015), que consistiu em um estudo de caso sobre a competência em informação em escolas de ensino secundário da Malásia, os autores discutiram, no contexto da competência em informação, metodologias de pesquisa qualitativa e suas limitações, dentre elas, as limitações éticas e de tempo, bem como estratégias para superá-las.

Aspectos éticos relacionados a competência em informação, especialmente no que diz respeito ao plágio, podem ser observados no estudo Alfabetización informacional en la educación superior virtual: logros y desafíos de Baéz et al. (2012), que trata da educação virtual como uma alternativa para o acesso a um maior número de estudantes ao sistema de educação superior. Uma das categorias investigadas neste estudo refere-se às percepções e experiências de educadores de instituições de ensino superior da Colômbia sobre o desenvolvimento de programas de competência em informação a fim de especificar as transformações, avanços, rupturas, entre outros aspectos relacionados à educação virtual. Dentre os resultados, os autores identificaram que embora os pesquisados estejam dando os primeiros passos em direção a uma cultura de respeito aos direitos de autor, o plágio é uma questão preocupante. O plágio ocorre em parte devido a uma formação acadêmica deficiente no ensino primário e secundário, principalmente relacionado ao desenvolvimento de habilidades leitoras e habilidades de escrita, e ao desenvolvimento insuficiente de processos cognitivos complexos, como a interpretação. Este resultado indica que os estudantes, aos ingressarem na universidade, não são competentes em informação quanto ao uso ético e legal da mesma.

O artigo de Fyffe (2015), intitulado The value of information: normativity, epistemology, and LIS in Luciano Floridi, é uma reconstrução crítica da visão de Luciano Floridi sobre a Biblioteconomia. Floridi defende as dimensões normativas da Biblioteconomia sob o ponto de vista da Filosofia da Informação e associada à ética da informação, diferente de outros pontos de vista que se fundamentam na epistemologia social. De acordo com Fyffe (2015), o trabalho de Floridi ajuda a esclarecer o papel do bibliotecário com relação ao ciclo de vida da informação, principalmente no aspecto normativo, e à competência em informação.

Perspectivas em Gestão \& Conhecimento, João Pessoa, v. 6, n. 2, p. 225-249, jul./dez. 2016. 
Também oferece uma importante base conceitual para a compreensão do que é frequentemente chamado de "conhecimento como um bem comum".

Foster (2013), no artigo intitulado Information literacy as a facilitator of ethical practice in the professions, menciona a importância da competência em informação e da ética nas profissões. Este autor sugere que a competência em informação é fundamental para a atividade profissional e seu desenvolvimento deve estar no centro de educação profissional, uma vez que uma parte do conhecimento é obtido por meio da experiência e da formação, e outra grande parte é adquirido por meio dos resultados de pesquisa, orientações, precedentes legais e outras fontes de informação. Para Foster (2013), profissionais competentes em informação são capazes de localizar, interpretar corretamente e aplicar resultados de pesquisas, orientações profissionais e outras informações de forma plena e completa. A competência em informação, para este autor, é uma ferramenta essencial na prática ética das profissões em que tais resultados são susceptíveis de ter um efeito profundo sobre a vida dos indivíduos.

Santos e Casarin (2014), no estudo intitulado "Habilidades informacionais abordadas em instrumentos de avaliação de competência informacional", analisam alguns instrumentos de avaliação da competência em informação. Uma das questões analisadas nos instrumentos refere-se ao uso ético da informação, com base no quinto parâmetro da ACRL (2000, p. 14, tradução nossa), que consiste em: "o estudante competente em informação compreende muitas questões econômicas, legais e sociais que rodeiam o uso da informação, acessa e utiliza a informação de forma ética e legal". O estudo demonstrou que a questão ética ainda é pouco explorada nos instrumentos de avaliação. Salienta-se que o desenvolvimento desta competência, enquanto processo de ensino-aprendizagem, pressupõe a etapa da avaliação. A avaliação, de acordo com Santos e Casarin (2014, p. 135), "permite traçar um diagnóstico que fornece indicadores para melhorar a aplicação dos programas e atividades sobre o tema e em muitos casos justifica a necessidade de implantação destes programas".

Nesta mesma perspectiva, o estudo de Holliday et al. (2014), intitulado An information literacysnapshot: authentic assessment across the curriculum, trata da avaliação da competência em informação dos estudantes com base nos cinco parâmetros da ACRL (2000), abrangendo assim a questão ética correspondente ao quinto parâmetro.

A partir da revisão dos artigos brasileiros, pode-se observar algumas associações da competência em informação com a ética. O estudo de Almeida e Céndon (2015), por exemplo, teve por objetivo verificar o impacto dos treinamentos para o uso do Portal de Periódicos da Capes no nível da competência em informação. O trabalho menciona a ética ao referir-se aos padrões desta competência para o ensino superior da ACRL (2000), mais especificamente no quinto padrão.

Alves e Arcará (2014) indicam alguns estudos diacrônicos de revisão e de comparação sobre competência em informação em nível mundial e investigam modelos em contexto universitário e suas respectivas aplicações. A ética, neste estudo, aparece em três momentos: em uma menção ao documento da ACRL (2000), que contém os padrões relacionados ao processo informativo, sendo que o quinto trata dos aspectos econômicos, legais e sociais do uso da informação; em uma citação do documento Competencias informáticas $e$ informacionales $(\mathrm{Cl}$ ) en los estudios de grado (CRUE UNIVERSIDADES ESPANHOLAS, 2012), que define habilidades relacionadas ao computador, aos programas, à rede e à informação, e dentre as habilidades relacionadas à informação, está a habilidade de utilização e comunicação da informação de forma eficaz, ética e legal, com o fim de construir conhecimento; por fim, nas considerações finais, em que os autores afirmam ser de competência dos bibliotecários, docentes, investigadores e instituições documentais e educativas proporcionar o desenvolvimento de habilidades para procurar, encontrar, avaliar e usar a informação apropriada e de forma ética.

Perspectivas em Gestão \& Conhecimento, João Pessoa, v. 6, n. 2, p. 225-249, jul./dez. 2016. 
No estudo de Bem e Coelho (2015), que trata da relação entre competência em informação e aprendizagem organizacional, há uma breve menção às dimensões da competência em informação propostas por Vitorino e Piantola (2012), assim, a ética, neste estudo, é citada como uma dessas dimensões fundamentadas por estas autoras.

Duarte, Mata e Caldin (2014) abordam o potencial da literatura infantil e a responsabilidade da Biblioteca Pública em selecionar as obras que irão compor o acervo infantil, além de, abordar a importância do desenvolvimento da competência em informação e explorar a dimensão estética dessa competência. Nesta perspectiva, a ética é mencionada também como uma das dimensões da competência em informação sob a visão de Rios (2010) e Vitorino e Piantola (2011).

O artigo de Orelo e Cunha (2013) apresenta discussões acerca das profissões, sob o olhar da Sociologia das Profissões, e discorre sobre a competência em informação do bibliotecário, apresentando as dimensões em que ela se desenvolve, sob a perspectiva de Rios (2010) e Vitorino e Piantola (2011), enfatizando também a dimensão estética. A ética, portanto, é mencionada brevemente no discurso sobre as dimensões.

O artigo de Cavalcante et al. (2011), que apresenta os resultados da pesquisa sobre a competência em informação dos estudantes da área da saúde na Universidade Federal do Ceará, contém uma única menção à ética, apontando-a como uma das implicações teóricas e práticas do estudo. Para estes autores, a formação dos futuros profissionais em saúde, com relação à competência em informação, implica em "compreender as questões culturais, éticas, legais e sociais relacionadas ao uso da informação obtida" (CAVALCANTE et al., 2011, p. 92).

Ceretta e Marzal (2011) refletem sobre o papel da competência em informação como forma de fortalecer as habilidades de leitura. A ética, neste estudo, é citada em diversas partes do texto associada ao uso da informação, como, por exemplo, no conceito do Chartered Institute of Library and Information Professionals (CILIP): "alfabetización informacional es saber cuándo y por qué se necesita información, dónde encontrarla, y cómo valorarla, utilizarla y comunicarla de forma eficaz y ética" (ABELL et al., 2004, p. 79).

Cerigatto e Casarin (2015) discutem o cenário de linguagens híbridas que nasce a partir do ciberespaço, do hipertexto e dos novos tipos de leitores que interagem com a informação, agora disseminada pelas mídias digitais. Estas autoras também fazem referência ao uso ético da informação como um dos elementos da competência em informação, juntamente com a localização e o acesso à informação, a comunicação da informação, o uso das habilidades de tecnologias da informação e comunicação (TIC) no processamento da informação e a media literacy, ou a competência midiática.

Competência em informação no ambiente de trabalho de órgãos públicos e o papel do bibliotecário neste contexto é o assunto do estudo de Coelho (2011). O uso ético da informação é mencionado nos resultados da pesquisa como uma das habilidades mais relevantes a serem adquiridas pelo servidor de órgão público.

Cuevas-Cervero, Marques e Paixão (2014) examinam questões com grande trajetória histórica e carga política - cultura, cidadania e alfabetização - a fim de destacar a importância que adquirem no atual contexto e a necessidade de instaurar uma autêntica Cultura da Informação. Neste estudo, a ética é vinculada à dimensão axiológica, que segundo CuevasCervero, Marques e Paixão (2014, p. 44 apud AREA, 2012) diz respeito à:

dar-se conta de que as TIC não são neutras, e mais, que podem afetar significativamente o ambiente cultural e político de nossa sociedade. Vincula-se também à formação ética e democrática no que diz respeito ao uso da informação e da tecnologia e à rejeição a atitudes contrárias a estes preceitos. 
A dimensão axiológica faz parte de um modelo de alfabetização no uso das TIC que contém cinco dimensões: instrumental; cognitivo-intelectual; sócio comunicacional; axiológica; e, emocional (CUEVAS-CERVERO; MARQUES; PAIXÃO, 2014).

Fidelis e Barbosa (2014) buscam entender a valorização e a adoção, por gestores na área educacional, de comportamentos e valores que promovam a competência em informação nas organizações. Nessa perspectiva, a ética é citada como parâmetro fundamental para lidar com a informação, uma vez que, de acordo com estes autores,

\begin{abstract}
um profissional precisa ser íntegro, ou seja, tem que desenvolver um comportamento que gere confiança nos outros membros da organização. Para isso, é preciso coerência entre o que ele prega e as suas práticas. Ter capacidade para lidar com a informação de forma direta, sincera e sem distorções. Não utilizar a informação para interesses próprios em detrimento dos interesses organizacionais e nem manipulá-la para justificar decisões já tomadas (FIDELIS; BARBOSA, 2014, p. 9).
\end{abstract}

Gasque (2011) apresenta o resultado da pesquisa de doutorado realizada com o objetivo de identificar a relação existente entre o pensamento reflexivo, proposto por Dewey (1979) e as habilidades empregadas na busca e no uso da informação na comunicação científica por pesquisadores em formação, alunos de mestrado e de doutorado. Neste estudo, a ética é associada ao uso da informação. Segundo Gasque (2011, p. 24), "buscar e usar informação são processos que abrangem [...] valores pessoais, motivações, crenças, visão crítica e atitudes como responsabilidade e ética".

Manabe et al. (2014) compararam alguns fatores do comportamento informacional de vinte acadêmicos ingressantes e dezenove concluintes do curso de Biblioteconomia de uma universidade pública do interior do Paraná. Neste estudo, a ética é citada nas considerações finais, onde os autores observam que é "imprescindível que todos os acadêmicos tenham determinadas habilidades para identificar, buscar, reconhecer, analisar e avaliar a informação que necessitam de forma ética e crítica" (MANABE et al., 2014, p. 54).

O estudo de Santos e Freire (2012), que teve como objetivo verificar formas de aprendizagem utilizadas pelos professores associados I do Centro de Tecnologia da Universidade Federal da Paraíba (UFPB) no desenvolvimento de conhecimentos/habilidades em recursos informacionais e tecnológicos, aponta a ética como um dos critérios para avaliar criticamente a informação.

Santos e Machado (2015) relatam uma experiência interdisciplinar e intersetorial vivida por bibliotecários, professores e graduandos envolvidos na construção do letramento informacional, mais especificamente na busca do domínio de capacidades de desvendamento do universo informacional acadêmico. Neste estudo, a ética está em conceitos de competência em informação associada ao uso da informação.

Victorelli (2011) apresenta um panorama a respeito da percepção e perspectivas do público adolescente, considerado como interagente em potencial para a TV digital estabelecendo sua relação com a competência em informação e contribuindo com parâmetros norteadores como subsídio às ações de gestão da comunicação na sociedade contemporânea. A ética é mencionada brevemente neste estudo como importante para os indivíduos no uso da informação. Para a autora, "é fundamental que os cidadãos contemporâneos de modo geral e, em especial os adolescentes adquiram habilidades que envolvam a competência em informação para que possam se inserir com ética e legalidade no universo movido pela informação em todas as suas dimensões" (VICTORELLI, 2011, p. 50). 
Serra (2014) descreve o que são os livros digitais, as possibilidades de aquisição e acesso e as dificuldades de sua utilização nas bibliotecas. Menciona a ética uma única vez em um conceito de competência em informação.

Varela e Barbosa (2012) analisam as possíveis trajetórias cognitivas decorrentes do processo de busca, recuperação e uso da informação, no âmbito da educação e na interrelação desta com a Ciência da Informação, na perspectiva da construção do conhecimento, demonstrando a aplicabilidade dos estudos cognitivos neste processo. Nesta perspectiva, a ética é citada como uma habilidade da alfabetização informacional para partilhar a informação com respeito, de acordo com os padrões da American Association of School Librarians (AASL). A alfabetização informacional, de acordo com os padrões da AASL, engloba três tipos de conhecimento e de habilidades: para encontrar a informação (localização e recuperação documental e bibliográfica; manejo de ferramentas tecnológicas e manejo de fontes de informação); para usar a informação (habilidades de pensamento, estudo e investigação, produção e apresentação); para partilhar e atuar eticamente com respeito à informação (VARELA; BARBOSA, 2012).

O objetivo do estudo de Vick e Nagano (2015) foi investigar como as competências em informação influenciam o trabalho de equipes acadêmicas em projetos de inovação, no momento em que essas criam conhecimento. A ética é citada em conceitos da competência em informação, associada ao uso crítico da informação.

No estudo de Garcia e Pinheiro (2015), que trata da aproximação entre a competência em informação e a abordagem das competências existente na Administração, a ética foi citada, primeiramente, como a sétima face ou categoria de competência em informação da pesquisadora australiana Christine Bruce. Segundo estes autores, esta categoria versa sobre a capacidade de usar a informação com sabedoria e ética. Num segundo momento, o uso ético da informação é citado em uma definição da UNESCO sobre competência em informação.

Valentim, Bitencourt Jorge e Ceretta-Soria (2014) analisam as relações entre competência em informação, gestão da informação e gestão do conhecimento. A ética novamente está em uma menção às faces ou categorias de Bruce (1997), mais especificamente na sexta categoria.

Belluzo, Santos e Almeida Júnior (2014), por sua vez, ao escrever sobre a aproximação teórica existente entre as temáticas competência em informação e mediação da informação, mencionam a ética ao explicitar que estas temáticas referem-se às ações de interferência realizadas por mediadores no processo de ensino aprendizagem de competências e habilidades informacionais. Neste caso, o mediador interfere para que ocorra uma mobilização de conhecimentos e a internalização de fundamentos conceituais, atitudinais e de habilidades específicas à compreensão da informação e de sua abrangência, em busca da fluência e das capacidades necessárias à geração do conhecimento novo e sua aplicabilidade legal e ética ao cotidiano das pessoas e das comunidades ao longo da vida.

Nessa mesma perspectiva, o estudo de Neves (2011) aborda a importância da discussão da mediação da informação e da competência em informação no aspecto da inclusão sociodigital. A ética é citada como uma das habilidades do mediador competente em informação.

Noutro trabalho, Rasteli e Cavalcante (2013), ao mapear os atributos da competência (conhecimentos, habilidades e atitudes) necessários à atuação do profissional bibliotecário como mediador de leitura em bibliotecas públicas, afirmam que uma conduta pautada na ética é importante na formação do bibliotecário como mediador.

Duarte et al. (2013) apresentam um relato de experiência extensionista idealizada por docentes vinculadas ao Departamento de Ciência da Informação da Universidade Federal da Paraíba (DCI/UFPB), com o objetivo de promover o desenvolvimento da competência em informação dos estudantes do 3 o ano de algumas escolas de João Pessoa. Faz-se neste estudo 
uma única menção à ética relacionada ao papel da escola: "a escola passa a compartilhar uma participação fundamental na construção das competências, uma vez que seu objetivo é preparar o cidadão para uma participação ética na sociedade (DUARTE et al., 2013, p. 557).

Dudziak (2011) propõe uma reflexão a respeito das diferentes concepções pedagógicas possíveis a serem utilizadas nos processos de educação para a competência em informação. Nessa perspectiva, a ética aparece relacionada a uma sociedade inclusiva e à pedagogia da emancipação. O domínio emancipatório, de acordo com Dudziak (2011, p. 180), "significa exercer o autoconhecimento voltado para a mudança e aperfeiçoamento social que busca valores como a solidariedade, o respeito à individualidade, liberdade e comprometimento consigo mesmo e com o grupo". Além disso, do ponto de vista da emancipação, a competência em informação assume uma dimensão crítica.

Ações de extensão das bibliotecas universitárias direcionadas à comunidade externa e aos campi são discutidas no estudo de Ferreira (2012). A competência em informação, ou letramento informacional como cita o autor, é uma das propostas de ação extensionista que bibliotecários podem desenvolver nas comunidades onde já existem bibliotecas ou salas de leitura. $O$ autor defende que projetos de extensão que busquem trabalhar o letramento informacional precisam enfatizar a capacitação dos usuários para utilizarem as TIC em seu processo de auto aprendizado e também conscientizá-los sobre as implicações legais, éticas e os riscos que se aplicam a essas ferramentas nas sociedades complexas.

O estudo de Gomes e Dumond (2015) objetivou discutir as possíveis inter-relações entre o uso de fontes de informação e a competência em informação. Neste contexto, a ética é citada na revisão de literatura associada às questões de plágio e propriedade intelectual.

Moraes, Furtado e Tomaél (2015) mapeiam uma rede de citações dos autores que publicaram trabalhos sobre competência em informação na base de dados Scopus no ano de 2012. Na revisão de literatura, a ética é citada por meio do estudo de Dudziak (2001), que aborda o desenvolvimento da competência em informação representado por três concepções: a informação, com ênfase nas tecnologias; o conhecimento, com ênfase nos processos cognitivos; e a inteligência, com ênfase no aprendizado ao longo da vida. Esta última concepção engloba não só conhecimentos e habilidades, como também a noção de valores atrelada à dimensão social do indivíduo, incluindo a ética, a autonomia, a responsabilidade, a criatividade, o pensamento crítico e o "aprender a aprender", com ênfase no cidadão enquanto ser social.

Vieira, Baptista e Cuevas Cerveró (2013) discutem o perfil do bibliotecário 2.0 a partir da realidade colaborativa e inovadora presente nas mídias sociais que faz com que ele interaja com estas muitas mídias procurando responder às competências profissionais e pessoais que o ambiente informacional moderno necessita. "Obedecer às normas éticas e interagir adequadamente com outras pessoas online" [...] (VIEIRA; BAPTISTA; CUEVAS CERVERÓ, 2013, p. 51) consta neste estudo como uma das dez habilidades que os bibliotecários devem possuir para trabalhar com as mídias sociais em bibliotecas.

\section{METODOLOGIA}

Esta pesquisa caracteriza-se como bibliográfica (KÖCHE, 2008), exploratória e descritiva (SANTOS, 2000). O processo de busca ocorreu no mês de setembro de 2015. Investigou-se nas bases de dados Library and Information Science Abstracts (LISA), Scopus, Education Resources Information Center (ERIC) e Web of Science (WoS) o quantitativo de artigos científicos sobre competência em informação publicados em periódicos acadêmicos da área de Ciência Social Aplicada no período de janeiro de 2011 a setembro de 2015.

O período de cobertura da busca bibliográfica escolhido deve-se ao fato de que se trata de uma área em pleno desenvolvimento e caracterizada como um fenômeno complexo,

Perspectivas em Gestão \& Conhecimento, João Pessoa, v. 6, n. 2, p. 225-249, jul./dez. 2016. 
ou seja, sujeita a evoluções e transformações constantes no cenário da Ciência da Informação. A busca em um período muito longo poderia recuperar documentos que não interessassem à pesquisa, já que o intuito é caracterizar uma área que tem apresentado evolução contínua e, dentro desta, a questão da ética ainda é pouco associada ao termo.

Para o levantamento bibliográfico, utilizou-se as formas mais recorrentes do termo "competência em informação", nos idiomas inglês, espanhol e português entre aspas, que se apresentam na literatura (information literacy; information skills; information competencies; informed learning; alfabetización informacional; competencias informacionales; desarrollo de habilidades en información; destrezas de información; alfabetización en información; competencias en información; competencias informativas; competência em informação; alfabetização em informação; competência informacional). Utilizou-se o recurso de pesquisa avançada, que permitiu a associação de operadores booleanos e uso de filtros para o refinamento da pesquisa. Optou-se por recuperar apenas artigos de periódicos acadêmicos revisados por pares da área de Ciências Sociais Aplicadas (ver Quadro 1).

A pesquisa nos periódicos brasileiros da área de Ciência da Informação e Biblioteconomia indexados na Base de Dados Referencial de Artigos de Periódicos em Ciência da Informação (BRAPCI) foi realizada no mesmo período. Optou-se por recuperar apenas artigos completos, de maior relevância, e que contivessem no título e/ou no resumo e/ou nas palavras-chaves pelo menos um dos seguintes termos: competência em informação; competência informacional; information literacy; alfabetização informacional; e, alfabetização em informação.

Num segundo momento, foram quantificados os artigos sobre competência em informação que contivessem alguma menção à ética. Nas bases de dados internacionais, utilizou-se as expressões relacionadas a competência em informação em inglês, espanhol e português, associadas aos seguintes termos: ethical; professional ethics; ética profesional; e, ética. Os resultados foram ordenados pelo critério de relevância. Para os fins deste trabalho, optou-se por apresentar apenas os quatro primeiros artigos mais relevantes de cada Base de Dados (ver Quadro 2).

Esta mesma quantificação foi realizada com os artigos sobre competência em informação publicados nos periódicos brasileiros. A identificação do assunto "ética" nestes artigos ocorreu por meio da leitura dos títulos, resumos e palavras-chave e utilização da ferramenta "localizar" no restante do texto.

\section{RESULTADOS}

Na sociedade contemporânea, a informação constitui-se em um recurso que, se adequadamente gerenciado, organizado e disseminado, pode estimular novos conhecimentos em determinada área do conhecimento, contribuir nas tomadas de decisões e resolução de problemas e levar pesquisadores ao encontro de informações úteis à sua realidade investigativa (BOCCATO, 2006). Por meio da pesquisa bibliográfica, é possível identificar a literatura pertinente à área de conhecimento a ser pesquisada, bem como reconhecer o enfoque e/ou perspectivas nas quais o assunto foi tratado na literatura científica.

Nesta perspectiva, apresenta-se no Quadro 1 o quantitativo de artigos científicos sobre competência em informação indexados nas bases de dados internacionais LISA, SCOPUS, ERIC e WOS, obtido por meio do levantamento bibliográfico realizado no período de janeiro 2011 a setembro de 2015. 
Quadro 1 - Número de artigos científicos, por ano (janeiro de 2011 - setembro de 2015), sobre competência em informação em bases de dados internacionais

\begin{tabular}{|l|l|l|l|l|l|l|}
\hline \multicolumn{1}{|c|}{ BASE } & \multicolumn{5}{|c|}{ ANO DE PUBLICAÇÃO } \\
\hline & 2011 & 2012 & 2013 & 2014 & 2015 & Total \\
\hline SCOPUS & 272 & 258 & 268 & 309 & 197 & 1.304 \\
\hline LISA & 295 & 305 & 314 & 230 & 83 & 1.225 \\
\hline ERIC & 134 & 144 & 108 & 91 & 55 & 532 \\
\hline WoS & 105 & 82 & 99 & 94 & 69 & 449 \\
\hline
\end{tabular}

Fonte: Elaborado pelas autoras

Observa-se no Quadro 1 um número expressivo de publicações nos últimos 5 anos sobre competência em informação, totalizando 3.510 artigos científicos. Dentre as bases de dados pesquisadas, a Scopus contém a maior quantidade de publicações, com 1.304 artigos. Em seguida, a LISA é a base com maior quantidade, contendo 1.225 artigos. Na ERIC e na WoS foram recuperados, respectivamente, 532 e 449 artigos.

Sobre este quantitativo de publicações, é possivel realizar algumas considerações com base na literatura já publicada. Por exemplo, há 14 anos, Dudziak (2001) fez um levantamento dos trabalhos publicados sobre competência em informação no período de 1974 a $2000 \mathrm{em}$ algumas bases de dados multidisciplinares internacionais. Àquela época, utilizando o termo information literacy, a autora recuperou 590 publicações na base LISA, 716 na base ERIC e 118 na WoS, totalizando 1.429 publicações em um período aproximado de 26 anos. A base Scopus não fez parte do levantamento desta autora. Ao se comparar os números da pesquisa de Dudziak (2001) com os resultados da atual pesquisa, que abrange somente os últimos 5 anos e artigos científicos, constata-se um aumento considerável na produção bibliográfica sobre a temática nas bases consultadas. A compilação das publicações encontradas nas bases LISA, ERIC e WoS totalizou 2.206 artigos, o que significa, em percentual, quase o dobro dos resultados encontrados por Dudziak (2001).

Um novo levantamento sobre a temática foi realizado por Dudziak (2010) nas bases WoS e Scopus, abrangendo o período de 2000 a 2010. Como estratégia de busca na WoS, Dudziak (2010) utilizou a expressão information literacy como tópico, opção default do sistema. O mesmo levantamento foi realizado na Base de Dados online Scopus, com a expressão "information literacy" inicialmente recuperada no campo keyword. De acordo com esta autora, foram recuperados 928 documentos na WoS e 615 na Scopus num período de 10 anos. Observa-se novamente um aumento expressivo da produção, sendo que na atual pesquisa, que abrange um período de 5 anos, foram recuperados 449 artigos na WoS e 1.304 na Scopus. A expressividade da produção científica sobre competência em informação na base Scopus, por exemplo, denota uma preocupação dos pesquisadores em desmitificar o tema e desenvolver estudos, seja de cunho teórico ou de ações a fim de disseminar o assunto nas mais diversas instâncias da literatura.

Nesta perspectiva, Bawden (2002) observa que a competência em informação é um tema central nas ciências da documentação. Ela está ligada a variadas questões, como ao excesso de informação, a aprendizagem ao longo da vida, a gestão do conhecimento e ao crescimento da sociedade da informação. Assim, esta é uma temática que tem sido cada vez mais apresentada na literatura. Virkus (2003) ressalta que a competência em informação vem 
se tornando área de interesse de bibliotecários e demais profissionais da informação desde 1974, principalmente em países de língua inglesa, como Estados Unidos e Austrália. Na Europa, o autor observou que a partir dos anos de 1998, 1999 e 2000 houve um interesse significativo pela temática neste contexto.

Contendo a associação do termo "ética" à competência em informação, o Gráfico 1 apresenta a quantidade de artigos científicos indexados nas bases de dados internacionais.

Gráfico 1 - Número de artigos científicos sobre competência em informação e ética publicados nos últimos cinco anos (janeiro de 2011- setembro de 2015) nas bases de dados internacionais

\section{Artigos científicos sobre competência em informação e} ética em bases de dados internacionais (2011- 2015)

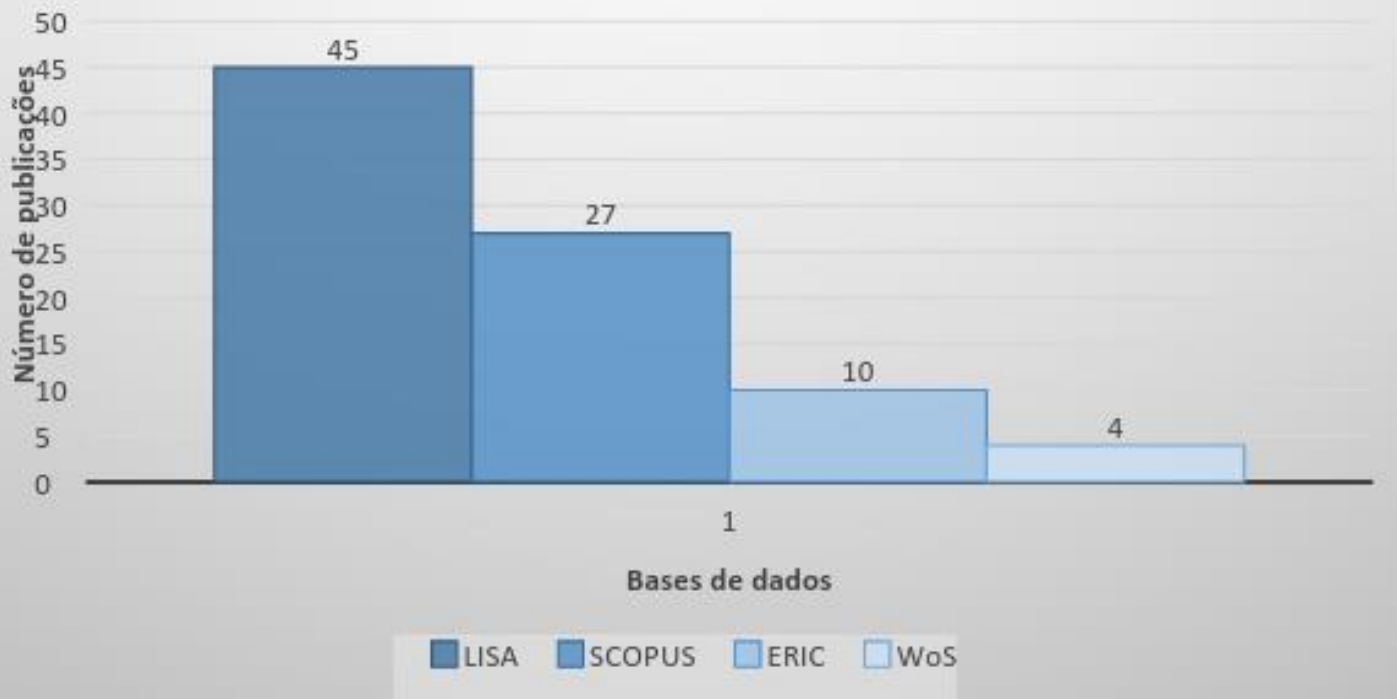

Fonte: Elaborado pelas autoras

Foram recuperados 86 artigos científicos sobre competência em informação e ética nas bases de dados pesquisadas. A base LISA apresenta o maior número de publicações, com 45 artigos. Em seguida, a base Scopus aparece com 27 publicações, a ERIC com 10 e a WoS com 4 artigos.

Pode-se perceber, ao comparar o Quadro 1 com o Gráfico 1, que há uma expressividade visível na Base LISA quando o assunto é competência em informação e, nesta, quando se associa à ética.

No Quadro 2, foram listados os quatro artigos mais relevantes em cada Base de Dados sobre a temática.

Quadro 2 - Artigos científicos mais relevantes sobre competência em informação e ética nas bases de dados LISA, ERIC, Scopus e WoS no período de janeiro 2011 a setembro 2015

\begin{tabular}{|c|c|c|c|c|}
\hline \multicolumn{5}{|c|}{$\begin{array}{l}\text { COMPETÊNCIA EM INFORMAÇÃO E ÉTICA NAS BASES DE DADOS INTERNACIONAIS: } \\
\text { os artigos mais relevantes }\end{array}$} \\
\hline \multicolumn{5}{|c|}{ Nota: Consulta realizada em 24 de setembro de 2015} \\
\hline $\begin{array}{l}\text { Base de } \\
\text { Dados }\end{array}$ & Título da Publicação & Autor & Ano & Link para acesso \\
\hline LISA & $\begin{array}{l}\text { Stewarding our first-year } \\
\text { students into the } \\
\text { information ecosystem: a } \\
\text { case study }\end{array}$ & $\begin{array}{l}\text { DEBOSE, Kyrille } \\
\text { Goldbeck; MILLER, } \\
\text { Rebecca K. }\end{array}$ & 2015 & $\begin{array}{l}\text { Texto completo não } \\
\text { disponível }\end{array}$ \\
\hline
\end{tabular}

Perspectivas em Gestão \& Conhecimento, João Pessoa, v. 6, n. 2, p. 225-249, jul./dez. 2016. 


\begin{tabular}{|c|c|c|c|c|}
\hline LISA & $\begin{array}{l}\text { Alfabetización } \\
\text { informacional en la } \\
\text { educación superior virtual: } \\
\text { logros y desafíos }\end{array}$ & $\begin{array}{l}\text { PINEDA BÁEZ, Clelia } \\
\text { et al. }\end{array}$ & 2012 & $\begin{array}{l}\text { http://www.scielo.org.ar/ } \\
\text { pdf/ics/n26/n26a05.pdf }\end{array}$ \\
\hline LISA & $\begin{array}{l}\text { Assessing students' } \\
\text { information literacy skills in } \\
\text { two secondary schools in } \\
\text { Singapore }\end{array}$ & CHANG, Yun-ke et al. & 2012 & $\begin{array}{l}\text { http://ojs.lboro.ac.uk/ojs/ } \\
\text { index.php/JIL/article/view } \\
\text { /PRA-V6-I2-2012-2/1718 }\end{array}$ \\
\hline LISA & $\begin{array}{l}\text { Information literacy as a } \\
\text { facilitator of ethical practice } \\
\text { in the professions }\end{array}$ & FOSTER, Marc & 2013 & $\begin{array}{l}\text { http://ojs.lboro.ac.uk/ojs/ } \\
\text { index.php/JIL/article/view } \\
\text { /PRA-V7-I1-2013-2/1806 }\end{array}$ \\
\hline ERIC & $\begin{array}{l}\text { An information } \\
\text { literacy snapshot: authentic } \\
\text { assessment across the } \\
\text { curriculum }\end{array}$ & $\begin{array}{l}\text { HOLLIDAY, Wend et } \\
\text { al. }\end{array}$ & 2015 & $\begin{array}{l}\text { http://crl.acrl.org/content } \\
\text { /early/2014/03/31/crl14- } \\
\text { 575.full.pdf+html }\end{array}$ \\
\hline ERIC & $\begin{array}{l}\text { Intelligence, academic self- } \\
\text { concept, and information } \\
\text { literacy: the role of } \\
\text { adequate perceptions of } \\
\text { academic ability in the } \\
\text { acquisition of knowledge } \\
\text { about information searching }\end{array}$ & $\begin{array}{l}\text { ROSMAN, Tom; } \\
\text { MAYER, Anne- } \\
\text { Kathrin; KRAMPEN, } \\
\text { Günter }\end{array}$ & 2015 & $\begin{array}{l}\text { http://files.eric.ed.gov/ful } \\
\text { ltext/EJ1060513.pdf }\end{array}$ \\
\hline ERIC & $\begin{array}{l}\text { An investigation of digital } \\
\text { literacy needs of students }\end{array}$ & $\begin{array}{l}\text { NELSON, Klara; } \\
\text { COURIER, Marcy; } \\
\text { JOSEPH, Gilbert W. }\end{array}$ & 2011 & $\begin{array}{l}\text { Texto completo não } \\
\text { disponível }\end{array}$ \\
\hline ERIC & $\begin{array}{l}\text { Writing and publishing in a } \\
\text { blended learning } \\
\text { environment to develop } \\
\text { students' scholarly digital } \\
\text { ethos }\end{array}$ & $\begin{array}{l}\text { FOGLEMAN, Jay; } \\
\text { NIEDBALA, Mona } \\
\text { Anne; BEDELL, } \\
\text { Francesca }\end{array}$ & 2013 & $\begin{array}{l}\text { Texto completo não } \\
\text { disponível }\end{array}$ \\
\hline Scopus & $\begin{array}{l}\text { Dimensões da competência } \\
\text { informacional }\end{array}$ & $\begin{array}{l}\text { VITORINO, Elizete } \\
\text { Vieira; PIANTOLA, } \\
\text { Daniela }\end{array}$ & 2011 & $\begin{array}{l}\text { http://revista.ibict.br/cie } \\
\text { nciadainformacao/index. } \\
\text { php/ciinf/article/view/19 } \\
\text { 18/1397 }\end{array}$ \\
\hline Scopus & $\begin{array}{l}\text { Competência informacional: } \\
\text { um olhar para a dimensão } \\
\text { estética }\end{array}$ & $\begin{array}{l}\text { ORELO, Eliane R. } \\
\text { M.; VITORINO, } \\
\text { Elizete Vieira }\end{array}$ & 2014 & $\begin{array}{l}\text { http://portaldeperiodicos } \\
\text {.eci.ufmg.br/index.php/pc } \\
\text { i/article/view/1614/1066 }\end{array}$ \\
\hline Scopus & $\begin{array}{l}\text { Habilidades informacionais } \\
\text { abordadas em instrumentos } \\
\text { de avaliação de } \\
\text { competência informacional }\end{array}$ & $\begin{array}{l}\text { SANTOS, Camila A. } \\
\text { dos; CASARIN, Helen } \\
\text { C. S. }\end{array}$ & 2014 & $\begin{array}{l}\text { http://www.ies.ufpb.br/o } \\
\text { js/index.php/ies/article/vi } \\
\text { ew/16501/12408 }\end{array}$ \\
\hline Scopus & $\begin{array}{l}\text { Alfabetización } \\
\text { informacional en la } \\
\text { educación superior virtual: } \\
\text { logros y desafíos }\end{array}$ & $\begin{array}{l}\text { PINEDA BÁEZ, Clelia } \\
\text { et al. }\end{array}$ & 2012 & $\begin{array}{l}\text { http://www.scielo.org.ar/ } \\
\text { scielo.php?script=sci_pdf } \\
\text { \&pid=S1851- } \\
\text { 17402012000100005\&lng } \\
=\text { es\&nrm=iso\&tlng=es }\end{array}$ \\
\hline WoS & $\begin{array}{l}\text { Habilidades informacionais } \\
\text { abordadas em instrumentos } \\
\text { de avaliação de } \\
\text { competência informacional }\end{array}$ & $\begin{array}{l}\text { SANTOS, Camila A. } \\
\text { dos; CASARIN, Helen } \\
\text { C. S. }\end{array}$ & 2014 & $\begin{array}{l}\text { http://www.ies.ufpb.br/o } \\
\text { js/index.php/ies/article/vi } \\
\text { ew/16501/12408 }\end{array}$ \\
\hline WoS & $\begin{array}{l}\text { The value of information: } \\
\text { normativity, epistemology, } \\
\text { and LIS in Luciano Floridi }\end{array}$ & FYFFE, Richard & 2015 & $\begin{array}{l}\text { https://muse.jhu.edu/jou } \\
\text { rnals/portal_libraries_and } \\
\text { the_academy/v015/15.2 } \\
\text {.fyffe.pdf }\end{array}$ \\
\hline
\end{tabular}

Perspectivas em Gestão \& Conhecimento, João Pessoa, v. 6, n. 2, p. 225-249, jul./dez. 2016. 


\begin{tabular}{|c|c|c|c|c|}
\hline WoS & $\begin{array}{l}\text { Information literacy skills of } \\
\text { secondary school students in } \\
\text { Singapore }\end{array}$ & FOO, Schubert et al. & 2014 & $\begin{array}{l}\text { http://www.ntu.edu.sg/h } \\
\text { ome/sfoo/publications/2 } \\
\text { 014/2014- } \\
\text { Aslib\%20Proceedings_fmt } \\
\text {.pdf }\end{array}$ \\
\hline WoS & $\begin{array}{l}\text { Overcoming time } \\
\text { and ethical constraints in } \\
\text { the qualitative data } \\
\text { collection process: a case of } \\
\text { information } \\
\text { literacy research }\end{array}$ & $\begin{array}{l}\text { YU, Halida; } \\
\text { ABDULLAH, Abrizah; } \\
\text { SAAT, Rohaida Mohd }\end{array}$ & 2014 & $\begin{array}{l}\text { http://lis.sagepub.com/co } \\
\text { ntent/46/3/243.full.pdf }+h \\
\text { tml }\end{array}$ \\
\hline
\end{tabular}

A partir da revisão dos artigos mais relevantes citados no Quadro 2 e publicados nos últimos 5 anos nas bases de dados pesquisadas, observa-se a ética inserida no contexto da competência em informação sob diversos aspectos.

No Brasil, a produção científica sobre competência em informação também se apresenta num ritmo crescente. No Gráfico 2, visualiza-se a quantidade de artigos publicados nas revistas brasileiras das áreas de Ciência da Informação e Biblioteconomia indexadas na BRAPCl, no período de janeiro 2011 a setembro de 2015.

Gráfico 2 - Número de artigos científicos sobre competência em informação publicados nos últimos cinco anos (janeiro de 2011- setembro de 2015) em periódicos brasileiros da área de Ciência da Informação e Biblioteconomia

Publicações em periódicos brasileiros sobre competência em informação (2011-2015)

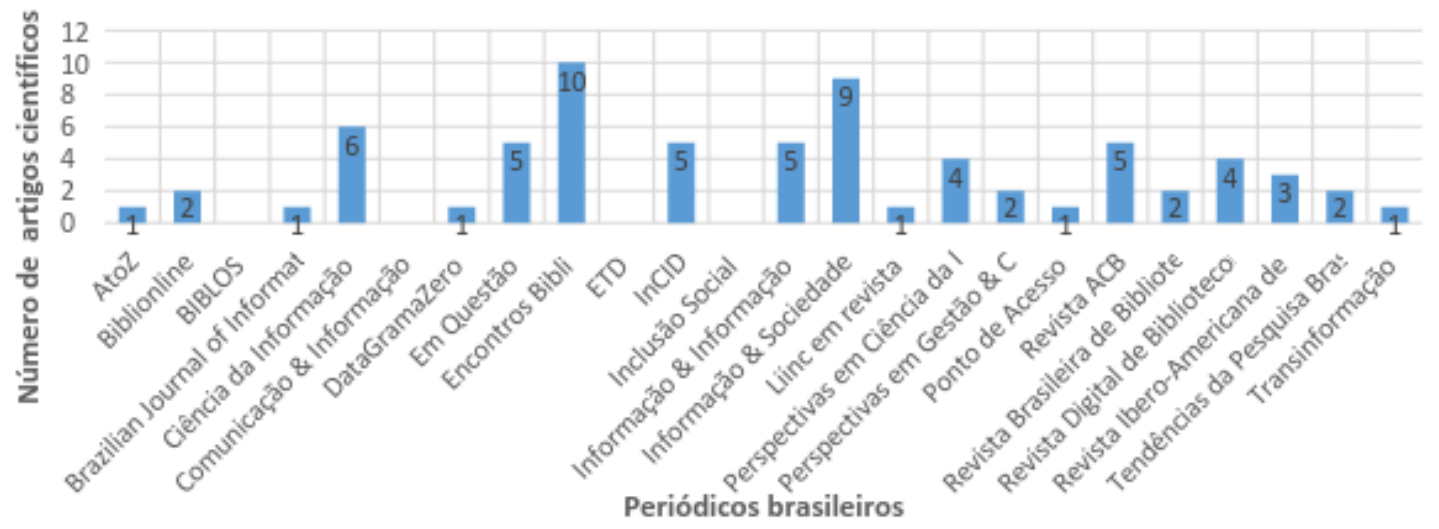

Fonte: Elaborado pelas autoras

Foram encontrados um total de 70 artigos científicos sobre competência em informação - que contém no título, resumo e/ou palavras-chaves os termos utilizados na busca - publicados em revistas brasileiras das áreas de Ciência da Informação e Biblioteconomia nos últimos 5 anos. Dentre as 24 revistas pesquisadas, há um maior número de artigos sobre a temática publicados nos seguintes periódicos: Encontros Bibli, com 10 artigos; Informação \& Sociedade, com 9 artigos; e Ciência da Informação, com 6 artigos. As revistas Em Questão, InCID, Informação \& Informação e Revista ACB publicaram, cada uma, 5 artigos no último quinquênio. As revistas Perspectivas em Ciência da Informação e Revista Digital de Biblioteconomia e Ciência da Informação contém 4 artigos publicados. Os demais periódicos aparecem com menos de 4 ou nenhum artigo completo publicado no período que abrange 
esta pesquisa. Há uma certa "vitalidade" da área, à medida que em 5 anos muito se tem pesquisado e escrito sobre o assunto, aproximando-se da casa das 100 publicações.

Ainda com relação às publicações brasileiras nos periódicos de Ciência da Informação e Biblioteconomia, identificou-se que dos 70 artigos recuperados, 34 contém no corpo do texto alguma menção à ética relacionada à competência em informação. Estes estudos estão listados no Quadro 3.

Quadro 3 - Artigos científicos sobre competência em informação e ética nos periódicos brasileiros das áreas de Ciência da Informação e Biblioteconomia

\section{COMPETÊNCIA EM INFORMAÇÃO E ÉTICA NOS PERIÓDICOS BRASILEIROS}

\begin{tabular}{|c|c|c|c|c|}
\hline $\begin{array}{l}\text { Título do } \\
\text { periódico }\end{array}$ & Título da Publicação & Autor & Ano & Link para acesso \\
\hline $\begin{array}{l}\text { Brazilian Journal } \\
\text { of Information } \\
\text { Science }\end{array}$ & $\begin{array}{l}\text { Política para a gestão de } \\
\text { livros digitais: a formação } \\
\text { do bibliotecário e dos } \\
\text { usuários }\end{array}$ & $\begin{array}{l}\text { SERRA, Liliana } \\
\text { Giusti }\end{array}$ & 2014 & $\begin{array}{l}\text { http://www2.marilia } \\
\text {.unesp.br/revistas/in } \\
\text { dex.php/bjis/article/ } \\
\text { view/4253/3092 }\end{array}$ \\
\hline $\begin{array}{l}\text { Ciência da } \\
\text { Informação }\end{array}$ & $\begin{array}{l}\text { Dimensões da competência } \\
\text { informacional }\end{array}$ & $\begin{array}{l}\text { VITORINO, } \\
\text { Elizete Vieira; } \\
\text { PIANTOLA, } \\
\text { Daniela }\end{array}$ & 2011 & $\begin{array}{l}\text { http://revista.ibict.b } \\
\text { r/cienciadainformac } \\
\text { ao/index.php/ciinf/a } \\
\text { rticle/view/1918/13 } \\
97\end{array}$ \\
\hline $\begin{array}{l}\text { Ciência da } \\
\text { Informação }\end{array}$ & $\begin{array}{l}\text { Mediação da informação } \\
\text { para agentes sociodigitais: o } \\
\text { salto }\end{array}$ & $\begin{array}{l}\text { NEVES, Bárbara } \\
\text { Coelho }\end{array}$ & 2011 & $\begin{array}{l}\text { http://revista.ibict.b } \\
\text { r/cienciadainformac } \\
\text { ao/index.php/ciinf/a } \\
\text { rticle/view/1954/14 } \\
38\end{array}$ \\
\hline $\begin{array}{l}\text { Ciência da } \\
\text { Informação }\end{array}$ & $\begin{array}{l}\text { Desarrollo de competencias } \\
\text { en información: otra } \\
\text { modalidad para fortalecer } \\
\text { las competencias lectoras }\end{array}$ & $\begin{array}{l}\text { CERETTA, María } \\
\text { Gladys; } \\
\text { MARZAL, } \\
\text { Miguel Ángel }\end{array}$ & 2011 & $\begin{array}{l}\text { http://revista.ibict.b } \\
\text { r/cienciadainformac } \\
\text { ao/index.php/ciinf/a } \\
\text { rticle/view/2012/14 } \\
35\end{array}$ \\
\hline $\begin{array}{l}\text { Ciência da } \\
\text { Informação }\end{array}$ & $\begin{array}{l}\text { Pesquisas na pós- } \\
\text { graduação: o uso do } \\
\text { pensamento reflexivo no } \\
\text { letramento informacional }\end{array}$ & $\begin{array}{l}\text { GASQUE, Kelley } \\
\text { Cristine } \\
\text { Gonçalves Dias }\end{array}$ & 2011 & $\begin{array}{l}\text { http://revista.ibict.b } \\
\text { r/cienciadainformac } \\
\text { ao/index.php/ciinf/a } \\
\text { rticle/view/1843/13 } \\
91\end{array}$ \\
\hline Em Questão & $\begin{array}{l}\text { Redes de citação: estudo de } \\
\text { rede de pesquisadores a } \\
\text { partir da competência em } \\
\text { informação }\end{array}$ & $\begin{array}{l}\text { MORAES, } \\
\text { Marcos; } \\
\text { FURTADO, } \\
\text { Renata Lira; } \\
\text { TOMAÉL, Maria } \\
\text { Inês }\end{array}$ & 2015 & $\begin{array}{l}\text { http://seer.ufrgs.br/ } \\
\text { index.php/EmQuest } \\
\text { ao/article/view/474 } \\
81 / 35085\end{array}$ \\
\hline Em Questão & $\begin{array}{l}\text { Avaliação do impacto do } \\
\text { treinamento sob a } \\
\text { perspectiva da competência } \\
\text { informacional: o caso do } \\
\text { Portal de Periódicos da } \\
\text { Capes }\end{array}$ & $\begin{array}{l}\text { ALMEIDA, } \\
\text { Fernanda } \\
\text { Gomes; } \\
\text { CENDÓN, } \\
\text { Beatriz } \\
\text { Valadares }\end{array}$ & 2015 & $\begin{array}{l}\text { http://seer.ufrgs.br/ } \\
\text { index.php/EmQuest } \\
\text { ao/article/view/494 } \\
\text { 51/34205 }\end{array}$ \\
\hline Em Questão & $\begin{array}{l}\text { Contribuição da } \\
\text { competência em }\end{array}$ & $\begin{array}{l}\text { VELENTIM, } \\
\text { Marta Lígia }\end{array}$ & 2014 & $\begin{array}{l}\text { http://seer.ufrgs.br/ } \\
\text { index.php/EmQuest }\end{array}$ \\
\hline
\end{tabular}




\begin{tabular}{|c|c|c|c|c|}
\hline & $\begin{array}{l}\text { informação para os } \\
\text { processos de gestão da } \\
\text { informação e do } \\
\text { conhecimento }\end{array}$ & $\begin{array}{l}\text { Pomim; } \\
\text { BITENCOURT } \\
\text { JORGE, Carlos } \\
\text { Francisco; } \\
\text { CERETTA- } \\
\text { SORIA, María } \\
\text { Gladys }\end{array}$ & & $\begin{array}{l}\text { ao/article/view/486 } \\
42 / 32122\end{array}$ \\
\hline Em Questão & $\begin{array}{l}\text { A competência } \\
\text { informacional } \\
\text { fundamentada na dimensão } \\
\text { ética }\end{array}$ & $\begin{array}{l}\text { MENEZES, } \\
\text { Priscila Lopes, } \\
\text { VITORINO, } \\
\text { Elizete Vieira }\end{array}$ & 2014 & $\begin{array}{l}\text { http://seer.ufrgs.br/ } \\
\text { index.php/EmQuest } \\
\text { ao/article/view/460 } \\
\text { 44/32151 }\end{array}$ \\
\hline Encontros Bibli & $\begin{array}{l}\text { Desenvolvendo a } \\
\text { competência informacional } \\
\text { das organizações por meio } \\
\text { da gestão de pessoas por } \\
\text { competências }\end{array}$ & $\begin{array}{l}\text { GARCIA, } \\
\text { Leonardo } \\
\text { Guimarães; } \\
\text { PINHEIRO, } \\
\text { Cintia Braga } \\
\text { Ferreira }\end{array}$ & 2015 & $\begin{array}{l}\text { https://periodicos.uf } \\
\text { sc.br/index.php/eb/ } \\
\text { article/view/1518- } \\
\text { 2924.2015v20n43p1 } \\
\text { 33/29964 }\end{array}$ \\
\hline Encontros Bibli & $\begin{array}{l}\text { Comportamento } \\
\text { informacional de } \\
\text { ingressantes e concluintes } \\
\text { de um curso superior }\end{array}$ & $\begin{array}{l}\text { MANABE, } \\
\text { Viviane Magda } \\
\text { Marques Luiz et } \\
\text { al. }\end{array}$ & 2014 & $\begin{array}{l}\text { https://periodicos.uf } \\
\text { sc.br/index.php/eb/ } \\
\text { article/view/1518- } \\
\text { 2924.2014v19n41p4 } \\
\text { 1/28287 }\end{array}$ \\
\hline Encontros Bibli & $\begin{array}{l}\text { Modelos e experiências de } \\
\text { competência em } \\
\text { informação em contexto } \\
\text { universitário }\end{array}$ & $\begin{array}{l}\text { ALVES, } \\
\text { Fernanda Maria } \\
\text { Melo; ALCARÁ, } \\
\text { Adriana } \\
\text { Rosecler }\end{array}$ & 2014 & $\begin{array}{l}\text { https://periodicos.uf } \\
\text { sc.br/index.php/eb/ } \\
\text { article/view/1518- } \\
\text { 2924.2014v19n41p8 } \\
\text { 3/28291 }\end{array}$ \\
\hline Encontros Bibli & $\begin{array}{l}\text { A competência } \\
\text { informacional para a } \\
\text { seleção e disseminação do } \\
\text { acervo literário infantil da } \\
\text { Biblioteca Pública Municipal } \\
\text { Barreiros Filho: olhar } \\
\text { estético }\end{array}$ & $\begin{array}{l}\text { DUARTE, } \\
\text { Evandro Jair; } \\
\text { MATA, Claudete } \\
\text { Terezinha da; } \\
\text { CALDIN, Clarice } \\
\text { Fortkamp }\end{array}$ & 2014 & $\begin{array}{l}\text { https://periodicos.uf } \\
\text { sc.br/index.php/eb/ } \\
\text { article/view/1518- } \\
\text { 2924.2014v19n41p5 } \\
\text { 9/28290 }\end{array}$ \\
\hline Encontros Bibli & $\begin{array}{l}\text { A competência em } \\
\text { informação e o bibliotecário } \\
\text { mediador da leitura em } \\
\text { biblioteca pública }\end{array}$ & $\begin{array}{l}\text { RASTELI, } \\
\text { Alessandro; } \\
\text { CAVALCANTE, } \\
\text { Lidia Eugenia }\end{array}$ & 2013 & $\begin{array}{l}\text { https://periodicos.uf } \\
\text { sc.br/index.php/eb/ } \\
\text { article/view/1518- } \\
\text { 2924.2013v18n36p1 } \\
\text { 57/24518 }\end{array}$ \\
\hline Encontros Bibli & $\begin{array}{l}\text { Trajetórias cognitivas } \\
\text { subjacentes ao processo de } \\
\text { busca e uso da informação: } \\
\text { fundamentos e } \\
\text { transversalidades }\end{array}$ & $\begin{array}{l}\text { VARELA, Ainda; } \\
\text { BARBOSA, } \\
\text { Marilene Lobo } \\
\text { Abreu }\end{array}$ & 2012 & $\begin{array}{l}\text { https://periodicos.uf } \\
\text { sc.br/index.php/eb/ } \\
\text { article/view/1518- } \\
\text { 2924.2012v17nesp1 } \\
\text { p142/22730 }\end{array}$ \\
\hline InCID & $\begin{array}{l}\text { O papel do bibliotecário de } \\
\text { referência na construção do } \\
\text { letramento informacional } \\
\text { acadêmico: uma prática } \\
\text { intersetorial e } \\
\text { interdisciplinar }\end{array}$ & $\begin{array}{l}\text { SANTOS, } \\
\text { Fabiana Pereira; } \\
\text { MACHADO, } \\
\text { Lucilia Regina } \\
\text { de Souza }\end{array}$ & 2014 & $\begin{array}{l}\text { http://www.revistas } \\
\text {.usp.br/incid/article/ } \\
\text { view/76319/pdf_36 }\end{array}$ \\
\hline InCID & $\begin{array}{l}\text { A relação entre } \\
\text { competência informacional } \\
\text { e aprendizagem } \\
\text { organizacional: um olhar a }\end{array}$ & $\begin{array}{l}\text { BEM, Roberta } \\
\text { Moraes; } \\
\text { COELHO, } \\
\text { Chistianne }\end{array}$ & 2014 & $\begin{array}{l}\text { http://www.revistas } \\
\text {.usp.br/incid/article/ } \\
\text { view/64337/pdf_34 }\end{array}$ \\
\hline
\end{tabular}




\begin{tabular}{|c|c|c|c|c|}
\hline & $\begin{array}{l}\text { partir do framework dos } 4 \\
\mathrm{I}(\mathrm{s})\end{array}$ & $\begin{array}{l}\text { Coelho de } \\
\text { Souza Reinisch }\end{array}$ & & \\
\hline InCID & $\begin{array}{l}\text { Competência em } \\
\text { informação na área da } \\
\text { Saúde }\end{array}$ & $\begin{array}{l}\text { CAVALCANTE, } \\
\text { Lídia Eugenia; } \\
\text { COSTA, Rosane } \\
\text { Maria; } \\
\text { NASCIMENTO, } \\
\text { Raimundo Cézar } \\
\text { Campos do; } \\
\text { SANTOS, Raquel } \\
\text { Jenyffer Souza }\end{array}$ & 2012 & $\begin{array}{l}\text { http://www.revistas } \\
\text {.usp.br/incid/article/ } \\
\text { view/42372/46043 }\end{array}$ \\
\hline $\begin{array}{l}\text { Informação \& } \\
\text { Informação }\end{array}$ & $\begin{array}{l}\text { A competência em } \\
\text { informação e sua avaliação } \\
\text { sob a ótica da mediação da } \\
\text { informação: reflexões e } \\
\text { aproximações teóricas }\end{array}$ & $\begin{array}{l}\text { BELLUZZO, } \\
\text { Regina Célia } \\
\text { Baptista; } \\
\text { SANTOS, Camila } \\
\text { Araújo dos; } \\
\text { ALMEIDA } \\
\text { JÚNIOR, } \\
\text { Oswaldo } \\
\text { Francisco de }\end{array}$ & 2014 & $\begin{array}{l}\text { http://www.uel.br/r } \\
\text { evistas/uel/index.ph } \\
\text { p/informacao/article } \\
\text { /view/19995/pdf_21 }\end{array}$ \\
\hline $\begin{array}{l}\text { Informação \& } \\
\text { Sociedade }\end{array}$ & $\begin{array}{l}\text { A práxis acadêmica de } \\
\text { inovação sob a ótica das } \\
\text { competências em } \\
\text { informação }\end{array}$ & $\begin{array}{l}\text { VICK, Thais } \\
\text { Elaine; } \\
\text { NAGANO, } \\
\text { Marcelo Seido }\end{array}$ & 2015 & $\begin{array}{l}\text { http://www.ies.ufpb } \\
\text {.br/ojs2/index.php/i } \\
\text { es/article/view/139/ } \\
13750\end{array}$ \\
\hline $\begin{array}{l}\text { Informação \& } \\
\text { Sociedade }\end{array}$ & $\begin{array}{l}\text { Novos leitores, novas } \\
\text { habilidades de leitura e } \\
\text { significação: desafios para a } \\
\text { media e information literacy }\end{array}$ & $\begin{array}{l}\text { CERIGATTO, } \\
\text { Mariana Pícaro; } \\
\text { CASARIN, Helen } \\
\text { de Castro Silva }\end{array}$ & 2015 & $\begin{array}{l}\text { http://www.ies.ufpb } \\
\text {.br/ojs2/index.php/i } \\
\text { es/article/view/039/ } \\
13199\end{array}$ \\
\hline $\begin{array}{l}\text { Informação \& } \\
\text { Sociedade }\end{array}$ & $\begin{array}{l}\text { Habilidades informacionais } \\
\text { abordadas em instrumentos } \\
\text { de avaliação de } \mathrm{Cl}\end{array}$ & $\begin{array}{l}\text { SANTOS, Camila } \\
\text { Araújo dos; } \\
\text { CASARIN, Helen } \\
\text { Castro Silva }\end{array}$ & 2014 & $\begin{array}{l}\text { http://www.ies.ufpb } \\
\text {.br/ojs2/index.php/i } \\
\text { es/article/view/1650 } \\
\text { 1/12408 }\end{array}$ \\
\hline $\begin{array}{l}\text { Informação \& } \\
\text { Sociedade }\end{array}$ & $\begin{array}{l}\text { A alfabetização que } \\
\text { necessitamos: informação e } \\
\text { comunicação para a } \\
\text { cidadania }\end{array}$ & $\begin{array}{l}\text { CUEVAS- } \\
\text { CERVERO, } \\
\text { Aurora; } \\
\text { MARQUES, } \\
\text { Márcia; } \\
\text { PAIXÃO, Pablo } \\
\text { Boaventura } \\
\text { Sales }\end{array}$ & 2014 & $\begin{array}{l}\text { http://www.ies.ufpb } \\
\text {.br/ojs2/index.php/i } \\
\text { es/article/view/1661 } \\
\text { 9/11489 }\end{array}$ \\
\hline $\begin{array}{l}\text { Informação \& } \\
\text { Sociedade }\end{array}$ & $\begin{array}{l}\text { As competências } \\
\text { profissionais do } \\
\text { bibliotecário } 2.0 \text { no espaço } \\
\text { da biblioteca universitária: } \\
\text { discussão da prática }\end{array}$ & $\begin{array}{l}\text { VIEIRA, David } \\
\text { Vernon; } \\
\text { BAPTISTA, Sofia } \\
\text { Galvão; } \\
\text { CUEVAS- } \\
\text { CERVERÓ, } \\
\text { Aurora }\end{array}$ & 2013 & $\begin{array}{l}\text { http://www.ies.ufpb } \\
\text {.br/ojs2/index.php/i } \\
\text { es/article/view/1564 } \\
\text { 4/9684 }\end{array}$ \\
\hline $\begin{array}{l}\text { Informação \& } \\
\text { Sociedade }\end{array}$ & $\begin{array}{l}\text { O bibliotecário e a } \\
\text { competência informacional }\end{array}$ & $\begin{array}{l}\text { ORELO, Eliane } \\
\text { Rodrigues } \\
\text { Mota; CUNHA, } \\
\text { Miriam } \\
\text { Figueiredo } \\
\text { Vieira da }\end{array}$ & 2013 & $\begin{array}{l}\text { http://www.ies.ufpb } \\
\text {.br/ojs2/index.php/i } \\
\text { es/article/view/1289 } \\
\text { 2/9682 }\end{array}$ \\
\hline LIINC em Revista & Competência informacional & COELHO, & 2011 & http://revista.ibict.b \\
\hline
\end{tabular}

Perspectivas em Gestão \& Conhecimento, João Pessoa, v. 6, n. 2, p. 225-249, jul./dez. 2016. 


\begin{tabular}{|c|c|c|c|c|}
\hline & $\begin{array}{l}\text { no ambiente de trabalho: } \\
\text { percepção do bibliotecário } \\
\text { de órgão público | }\end{array}$ & $\begin{array}{l}\text { Marlene } \\
\text { Morbeck }\end{array}$ & & $\begin{array}{l}\text { r/liinc/index.php/liin } \\
\text { c/article/view/408/2 } \\
81\end{array}$ \\
\hline $\begin{array}{l}\text { Perspectivas em } \\
\text { Ciência da } \\
\text { Informação }\end{array}$ & $\begin{array}{l}\text { Competência informacional: } \\
\text { um olhar para a dimensão } \\
\text { estética }\end{array}$ & $\begin{array}{l}\text { ORELO, Eliane } \\
\text { Rodrigues } \\
\text { Mota; } \\
\text { VITORINO, } \\
\text { Elizete Vieira } \\
\text { Vitorino }\end{array}$ & 2012 & $\begin{array}{l}\text { http://portaldeperio } \\
\text { dicos.eci.ufmg.br/in } \\
\text { dex.php/pci/article/ } \\
\text { view/1614/1066 }\end{array}$ \\
\hline $\begin{array}{l}\text { Perspectivas em } \\
\text { Gestão \& } \\
\text { Conhecimento }\end{array}$ & $\begin{array}{l}\text { Formas de aprendizagem no } \\
\text { desenvolvimento da } \\
\text { competência informacional } \\
\text { dos professores associados I } \\
\text { do centro de tecnologia da } \\
\text { UFPB }\end{array}$ & $\begin{array}{l}\text { SANTOS, } \\
\text { Mônica Paiva; } \\
\text { FREIRE, Gustavo } \\
\text { Henrique de } \\
\text { Araújo }\end{array}$ & 2012 & $\begin{array}{l}\text { http://periodicos.uf } \\
\text { pb.br/ojs/index.php } \\
\text { /pgc/article/view/12 } \\
658 / 8016\end{array}$ \\
\hline Revista ACB & $\begin{array}{l}\text { Comportamento e } \\
\text { competência em } \\
\text { informação: uma } \\
\text { experiência de extensão } \\
\text { universitária }\end{array}$ & $\begin{array}{l}\text { DUARTE, } \\
\text { Emeide } \\
\text { Nóbrega et al. }\end{array}$ & 2013 & $\begin{array}{l}\text { http://revista.acbsc. } \\
\text { org.br/racb/article/v } \\
\text { iew/859/pdf }\end{array}$ \\
\hline $\begin{array}{l}\text { Revista Brasileira } \\
\text { de } \\
\text { Biblioteconomia } \\
\text { e Documentação }\end{array}$ & $\begin{array}{l}\text { Percepções e perspectivas } \\
\text { dos adolescentes sobre a TV } \\
\text { digital }\end{array}$ & $\begin{array}{l}\text { VICTORELLI, } \\
\text { Danielli Santos } \\
\text { da Silva }\end{array}$ & 2011 & $\begin{array}{l}\text { http://rbbd.febab.or } \\
\text { g.br/rbbd/article/vie } \\
\text { w/182/185 }\end{array}$ \\
\hline $\begin{array}{l}\text { Revista Digital de } \\
\text { Biblioteconomia } \\
\text { \& Ciência da } \\
\text { Informação }\end{array}$ & $\begin{array}{l}\text { Transpondo muros, } \\
\text { construindo relações: uma } \\
\text { reflexão sobre bibliotecas } \\
\text { universitárias e extensão no } \\
\text { Brasil }\end{array}$ & $\begin{array}{l}\text { FERREIRA, } \\
\text { Rubens da Silva }\end{array}$ & 2012 & $\begin{array}{l}\text { http://periodicos.sb } \\
\text { u.unicamp.br/ojs/in } \\
\text { dex.php/rdbci/articl } \\
\text { e/view/1912/2033 }\end{array}$ \\
\hline $\begin{array}{l}\text { Revista Digital de } \\
\text { Biblioteconomia } \\
\text { \& Ciência da } \\
\text { Informação }\end{array}$ & $\begin{array}{l}\text { Em busca da pedagogia da } \\
\text { emancipação na educação } \\
\text { para a competência em } \\
\text { informação sustentável }\end{array}$ & $\begin{array}{l}\text { DUDZIAK, } \\
\text { Elisabeth } \\
\text { Adriana }\end{array}$ & 2011 & $\begin{array}{l}\text { http://periodicos.sb } \\
\text { u.unicamp.br/ojs/in } \\
\text { dex.php/rdbci/articl } \\
\text { e/view/1925/2046 }\end{array}$ \\
\hline $\begin{array}{l}\text { Tendências da } \\
\text { Pesquisa } \\
\text { Brasileira em } \\
\text { Ciência da } \\
\text { Informação }\end{array}$ & $\begin{array}{l}\text { Competência informacional } \\
\text { em comportamentos e } \\
\text { valores fundamentais à } \\
\text { gestão da informação nas } \\
\text { organizações }\end{array}$ & $\begin{array}{l}\text { FIDELIS, Joubert } \\
\text { Roberto } \\
\text { Ferreira; } \\
\text { BARBOSA, } \\
\text { Ricardo } \\
\text { Rodrigues }\end{array}$ & 2014 & $\begin{array}{l}\text { http://inseer.ibict.br } \\
\text { /ancib/index.php/tp } \\
\text { bci/article/view/123 } \\
\text { /164 }\end{array}$ \\
\hline Transinformação & $\begin{array}{l}\text { Possíveis relações entre o } \\
\text { uso de fontes de } \\
\text { informação e a competência } \\
\text { em informação }\end{array}$ & $\begin{array}{l}\text { GOMES, Marcos } \\
\text { Aurélio; } \\
\text { DUMONT, Lígia } \\
\text { Maria Moreira }\end{array}$ & 2015 & $\begin{array}{l}\text { http://periodicos.pu } \\
\text { c- } \\
\text { campinas.edu.br/se } \\
\text { er/index.php/transin } \\
\text { fo/article/view/2924 } \\
\text { /1962 }\end{array}$ \\
\hline
\end{tabular}

Fonte: Elaborado pelas autoras

Observa-se que os artigos de Santos e Casarin (2014), Orelo e Vitorino (2012) e Vitorino e Piantola (2011), publicados em revistas brasileiras, estão nos resultados mais relevantes recuperados nas bases de dados internacionais, o que demonstra que, neste cruzamento de buscas realizadas, já se fazem presentes e de forma relevante, artigos escritos por brasileiros sobre a competência em informação cujas reflexões se encaminham para uma 
institucionalização deste tema sob a perspectiva igualmente brasileira, "exportando" tais ideias para outros contextos.

Dentre os 34 artigos que tratam da competência em informação em âmbito nacional e que trazem alguma associação com a ética, pode-se dizer que há um de maior relevância. Trata-se do estudo de Menezes e Vitorino (2014), intitulado "A competência informacional fundamentada na dimensão ética", que apresenta a competência em informação associada aos elementos constituintes da mesma, demonstrando por meio de argumentos teóricos e conceituais, a relevância de atitudes e virtudes que tenham como pano de fundo a moral e a ética. O objetivo deste estudo foi "expor atitudes e virtudes tidas como básicas, que fundamentam a conduta dos Profissionais da Informação, tendo seu foco na dimensão ética [...]" (MENEZES; VITORINO, 2014, p. 87).

Menezes e Vitorino (2014) explicam que os Profissionais da Informação são orientados, desde sua formação, a atuar com proficiência e dinâmica nas atividades profissionais. As atividades destes profissionais são sustentadas pelo tripé conhecimentos, habilidades e atitudes, componentes que resultam na competência em informação. A ética, por sua vez, caracteriza-se pela busca da felicidade, pelo bem comum, pelo interesse coletivo como prioridade, por uma contemplação e interiorização do bem. A felicidade, no entanto, não pode separar-se de certas condições sociais que a aproximam ou a afastam de setores da sociedade. Para as autoras, não há verdadeira felicidade na miséria, na exploração, na falta de liberdade política, na discriminação racial, etc. A liberdade e o direito de escolha são quase uma condenação, pois o indivíduo assume a responsabilidade por suas escolhas e a cada opção ética tomada está a abdicação de alternativas que no final poderiam ser melhores. Assim, o conhecimento ético proporciona discernimento para o agir. Neste contexto, o estudo elenca algumas atitudes e virtudes que nutrem a dimensão ética. A estrutura da atitude é composta por componentes cognitivos (diz respeito à maneira como o objeto é percebido e às informações que já se conhecem sobre o mesmo), avaliativos ou afetivos (refere-se ao sentimento pró ou contra experimentado em relação ao objeto) e comportamentais (envolve a intenção do comportamento tida diante do objeto). Com relação às virtudes, pode-se identificar no estudo a referência à felicidade, ao amor, à coragem, à justiça, à tolerância, à humildade e ao humor. Para Menezes e Vitorino (2014), ação e prática são os termos que melhor definem a conduta ética, que pode ser compreendida como a orientação para as ações, envolvendo regras que norteiem o agir e auxiliem cidadãos a viver em sociedade.

A partir da identificação da produção científica internacional e nacional sobre competência em informação e da revisão dos artigos que contém a ética associada a essa "metacompetência", publicados no último quinquênio, percebe-se que há alguns elementos que se apresentam com frequência na literatura e estão relacionados à dimensão ética da competência em informação (ver Figura 1).

Observa-se que, principalmente em âmbito internacional, a ética se apresenta vinculada a competência em informação em iniciativas voltadas para a avaliação dos programas nas instituições de ensino e avaliação dos níveis de competência em informação dos estudantes. A ética é comumente mencionada como um dos aspectos contemplados nos instrumentos de avaliação, normalmente, com base no padrão 5 da ACRL (2000). 
Figura 1 - Elementos da dimensão ética da competência em informação com base na literatura

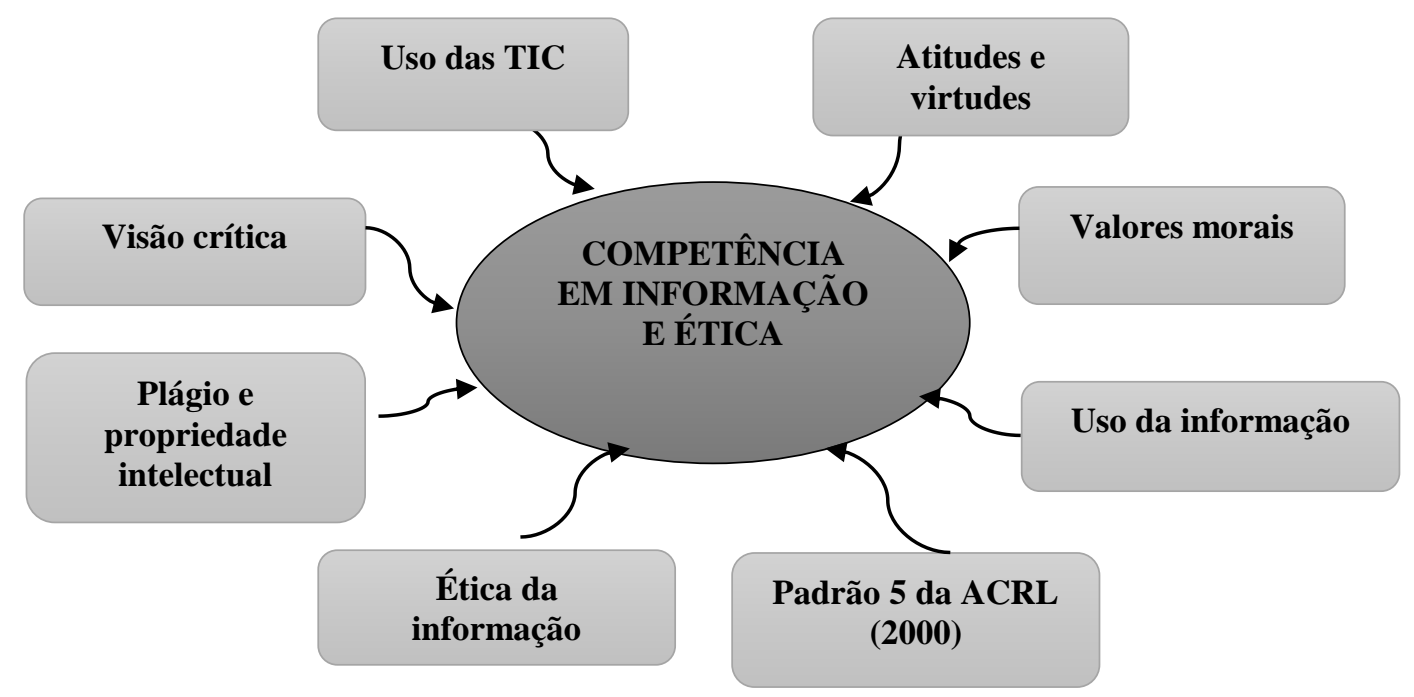

Fonte: Elaborado pelas autoras

Em âmbito nacional, a ética aparece frequentemente inserida nos conceitos de competência em informação e também em menções a documentos internacionais como o Information literacy competency standards for higher education da ACRL (2000). Além disso, há alguns estudos voltados para as dimensões desta competência, principalmente, que aprofundam a dimensão estética, e outros que citam as sete faces da pesquisadora Christiane Bruce.

\section{CONSIDERAÇÕES FINAIS}

A pesquisa bibliográfica realizada nas bases de dados LISA, Scopus, ERIC, WoS e nos periódicos brasileiros da área de Ciência da Informação e Biblioteconomia, no período de 2011 a 2015, sobre competência em informação e quanto a menção da ética, indica a existência de uma importante relação entre estas temáticas.

Em âmbito internacional e nacional, autores mencionam questões de plágio e propriedade intelectual associadas a competência em informação e à ética, bem como apontam para a importância do uso ético e legal da informação nas profissões, como é o caso de Baéz et al. (2012), Foster (2013) e Orelo e Cunha (2013), e pelos estudantes.

Apesar de ter ocorrido nos últimos anos um aumento expressivo na produção científica sobre o tema, não foram recuperados nesta pesquisa, estudos que aprofundem a dimensão ética da competência em informação, ou que tragam um detalhamento da ética no âmbito da competência, o que denota a necessidade de se investigar esta dimensão e de se traçar configurações e cenários a partir de práticas e vivências, além de se criar ações de formação inicial e continuada neste âmbito.

\section{REFERÊNCIAS}

ABELL, Angela et al. Alfabetización en información: la definición de CILIP (UK). Boletín de la Asociación Andaluza de Bibliotecarios, Espanha, n. 77, p. 79-84, dez. 2004. Disponível em: dialnet.unirioja.es/descarga/articulo/1302261.pdf. Acesso em: 6 out. 2015. 
ALMEIDA, Fernanda Gomes; CENDÓN, Beatriz Valadares. Avaliação do impacto do treinamento sob a perspectiva da competência informacional: o caso do Portal de Periódicos da Capes. Em Questão: Revista da Faculdade de Biblioteconomia e Comunicação da UFRGS, Porto Alegre, v. 21, n. 1, p. 26-50, jan./abr. 2015. Disponível em: http://seer.ufrgs.br/index.php/EmQuestao/article/view/49451/34205. Acesso em: 6 out. 2015.

ALVES, Fernanda Maria Melo; ALCARÁ, Adriana Rosecler. Modelos e experiências de competência em informação em contexto universitário. Encontros Bibli: Revista Eletrônica de Biblioteconomia e Ciência da Informação, Florianópolis, v. 19, n. 41, p. 83-104, set./dez., 2014. Disponível em: https://periodicos.ufsc.br/index.php/eb/article/view/1518924.2014v19n41p83/28291. Acesso em: 6 out. 2015.

ASSOCIATION OF COLLEGE AND RESEARCH LIBRARIES. Information literacy competency standards for higher education. Chicago, 2000. Disponível em: http://www.ala.org/acrl/sites/ala.org.acrl/files/content/standards/standards.pdf. Acesso em: 6 out. 2015.

BASE DE DADOS REFERENCIAIS DE ARTIGOS DE PERIÓDICOS EM CIÊNCIA DA INFORMAÇÃO. Publicações. Curitiba, 2014. Disponível em: http://www.brapci.ufpr.br/ic.php?dd99=journals. Acesso em: 6 out. 2015.

BAWDEN, David. Revisión de los conceptos de alfabetización informacional y alfabetización digital. Anales de Documentación, Murcia (ESP), v. 5, p. 361-408, 2002. Disponível em: http://revistas.um.es/analesdoc/article/view/2261/2251. Acesso em: 6 out. 2015.

BELLUZZO, Regina Célia Baptista; SANTOS, Camila Araújo dos; ALMEIDA JÚNIOR, Oswaldo Francisco de. A competência em informação e sua avaliação sob a ótica da mediação da informação: reflexões e aproximações teóricas. Informação \& Informação, Londrina, v. 19, n. 2 , p. 60 - 77, maio./ago. 2014. Disponível em: https://www.marilia.unesp.br/Home/Graduacao/PETBiblioteconomia/a-competencia-eminformacao..pdf. Acesso em: 6 out. 2015.

BEM, Roberta Moraes; COELHO, Chistianne Coelho de Souza Reinisch. A relação entre competência informacional e aprendizagem organizacional: um olhar a partir do framework dos 4 I (s). InCID: Revista de Ciência da Informação e Documentação, Ribeirão Preto, v. 5, n. 2, p.112-127, fev. 2015. Disponível em: http://www.revistas.usp.br/incid/article/viewFile/64337/pdf 34. Acesso em: 6 out. 2015.

BOCCATO, Vera Regina Casari. Metodologia da pesquisa bibliográfica na área odontológica e o artigo científico como forma de comunicação. Revista Odontológica da Universidade Cidade de São Paulo, São Paulo (SP), v. 18, n. 3, p. 265-274, set./dez. 2006. Disponível em: http://arquivos.cruzeirodosuleducacional.edu.br/principal/old/revista odontologia/pdf/setem bro dezembro 2006/metodologia pesquisa bibliografica.pdf. Acesso em: 4 dez. 2015.

CASARIN, Helen de Castro Silva Casarin; CERIGATTO, Mariana Pícaro. Novos leitores, novas habilidades de leitura e significação: desafios para a media e information literacy. Informação \& Sociedade: Estudos, João Pessoa, v. 25, n. 1, p. 39-52, jan./abr. 2015. Disponível em: http://www.ies.ufpb.br/ojs/index.php/ies/article/view/039/13199. Acesso em: 6 out. 2015.

CATTS, Ralph; LAU, Jesus. Towards Information Literacy Indicators. Paris: UNESCO, 2008. Disponível em: http://www.uis.unesco.org/Library/Documents/wp08 InfoLit en.pdf. Acesso em: 4 dez. 2015. 
CAVALCANTE, Lídia Eugenia et al. Competência em Informação na Área da Saúde. InCID: Revista de Ciência da Informação e Documentação, Ribeirão Preto, v. 3, n. 1, p. 87-104, jan./jun. 2012. Disponível em: http://www.revistas.usp.br/incid/article/viewFile/42372/46043. Acesso em: 6 out. 2015.

CERETTA, María Gladys; MARZAL, Miguel Ángel. Desarrollo de competencias en información: otra modalidad para fortalecer las competencias lectoras. Ciência da Informação, Brasília, v. 40 n. 3, p. 364-378, set./dez. 2011. Disponível em: http://revista.ibict.br/index.php/ciinf/article/view/2012/1435. Acesso em: 6 out. 2015.

CHANG, Yun-ke et al. Assessing students' information literacy skills in two secondary schools in Singapore. Journal of Information Literacy, Reino Unido, v. 6, n. 2, p. 18-34, dez. 2012. Disponivel em: http://ojs.lboro.ac.uk/ojs/index.php/JIL/article/view/PRA-V6-I2-2012-2/1718. Acesso em: 6 out. 2015.

COELHO, Marlene Morbeck. Competência informacional no ambiente de trabalho: percepção do bibliotecário de órgão público. Liinc em Revista, Rio de Janeiro, v. 7, n. 1, p. 170 - 196, mar. 2011. Disponível em: http://revista.ibict.br/liinc/index.php/liinc/article/view/408/281. Acesso em: 6 out. 2015.

CUEVAS-CERVERO, Aurora; MARQUES, Márcia; PAIXÃO, Pablo Boaventura Sales. A alfabetização que necessitamos: informação e comunicação para a cidadania. Informação \& Sociedade: Estudos, João Pessoa, v. 24, n. 2, p. 35-48, maio/ago. 2014. Disponível em: http://www.ies.ufpb.br/ojs/index.php/ies/article/view/16619/11489. Acesso em: 6 out. 2015.

CRUE UNIVERSIDADES ESPANHOLAS. Competencias informáticas e informacionales (CI2) en los estudios de grado. [s.I], 2012. Disponível em: http://ci2.es/sites/default/files/documentacion/ci2 estudios grado.pdf. Acesso em: 6 out. 2015.

DEBOSE, Kyrille Goldbeck; MILLER, Rebecca K. Stewarding our first-year students into the information ecosystem: a case study. Journal of Agricultural \& Food Information, Reino Unido, v. 16, n. 2, p. 123-133, abr. 2015. Disponível em: http://search.proquest.ez130.periodicos.capes.gov.br/lisa/docview/1683508591/268431FB81 134F47PQ/1 ?accountid=26576. Acesso em: 6 out. 2015.

DUARTE, Emeide Nóbrega et al. Comportamento e competência em informação: uma experiência de extensão universitária. Revista ACB: Biblioteconomia em Santa Catarina, Florianópolis, v. 18, n. 1, p. 553-575, jan./jun., 2013. Disponível em: http://revista.acbsc.org.br/racb/article/view/859/pdf. Acesso em: 6 out. 2015.

DUARTE, Evandro Jair; MATA, Claudete Terezinha da; CALDIN, Clarice Fortkamp. A competência informacional para seleção e disseminação do acervo literário infantil da biblioteca pública municipal Barreiros Filho: olhar estético. Encontros Bibli: Revista Eletrônica de Biblioteconomia e Ciência da Informação, Florianópolis, v. 19, n. 41, p. 59-82, 2014. Disponível em: https://periodicos.ufsc.br/index.php/eb/article/view/1518-2924.2014v19n41p 59/28290. Acesso em: 6 out. 2015.

DUDZIAK, Elisabeth Adriana. A information literacy e o papel educacional das bibliotecas. 2001. 187 f. Dissertação (Mestrado em Ciências da Comunicação)-Escola de Comunicações e Artes, Universidade de São Paulo, São Paulo, 2001. Disponível em: http://www.teses.usp.br/teses/disponiveis/27/27143/tde-

30112004151029/publico/Dudziak2.pdf. Acesso em: 4 dez. 2015. 
DUDZIAK, Elisabeth Adriana. Competência informacional: análise evolucionária das tendências da pesquisa e produtividade científica em âmbito mundial. Informação \& Informação, Londrina, v. $15, \quad$ n. 2 , p. $1-22$ jul./dez. 2010. Disponível em: http://www.brapci.ufpr.br/download.php?dd0=15609. Acesso em: 6 out. 2015.

DUDZIAK, Elisabeth Adriana. Em busca da pedagogia da emancipação na educação para a competência em informação sustentável. RDBC: Revista Digital de Biblioteconomia e Ciência da Informação, Campinas, v. 9, n. 1, p.166-183, jul./dez. 2011. Disponível em: http://www.sbu.unicamp.br/seer/ojs/index.php/rbci/article/view/502/pdf 8. Acesso em: 6 out. 2015.

FERREIRA, Rubens da Silva. Transpondo muros, construindo relações: uma reflexão sobre bibliotecas universitárias e extensão no Brasil. RDBC: Revista Digital de Biblioteconomia e Ciência da Informação, Campinas, v. 9, n. 2, p. 75-88, jan./jun. 2012. Disponível em: http://www.sbu.unicamp.br/seer/ojs/index.php/rbci/article/view/499/pdf 21. Acesso em: 6 out. 2015.

FIDELIS, Joubert Roberto Ferreira; BARBOSA, Ricardo Rodrigues. Competência informacional em comportamentos e valores fundamentais à gestão da informação nas organizações. Tendências da Pesquisa Brasileira em Ciência da Informação, Belo Horizonte, v. 7, n. 1, p. 118, jan./jun. 2014.2 Disponível em: http://inseer.ibict.br/ancib/index.php/tpbci/article/view/123/164. Acesso em: 6 out. 2015.

FOGLEMAN, Jay; NIEDBALA, Mona Anne; BEDELL, Francesca. Writing and publishing in a blended learning environment to develop students' scholarly digital ethos. Behavioral \& Social Sciences Librarian, v. 32, n. 2, p. 71-85, 2013. Disponível em: http://eric.ed.gov/?q=Writing+and+publishing+in+a+blended+\&id=EJ1004992. Acesso em: 4 dez. 2015.

FOSTER, M. Information literacy as a facilitator of ethical practice in the professions. Journal of Information Literacy, Reino Unido, v. 7, n. 1, p.18-29, 2013. Disponível em: http://ojs.lboro.ac.uk/ojs/index.php/JIL/article/viewFile/pra-v7-i1-2013-2/1806. Acesso em: 6 out. 2015.

FOO, Schubert et al. Information literacy skills of secondary school students in Singapore. Aslib Journal of Information Management, v. 66, n. 1, p. 54-76, jan. 2014. Disponível em: http://www.ntu.edu.sg/home/sfoo/publications/2014/2014-Aslib\%20Proceedings fmt.pdf. Acesso em: 6 out. 2015.

FYFFE, Richard. The value of information: normativity, epistemology, and LIS in Luciano Floridi. Libraries and the Academy, v. 15, n. 2, p. 267-286, abr. 2015. Disponível em: https://muse.jhu.edu/journals/portal libraries and the academy/v015/15.2.fyffe.pdf. Acesso em: 6 out. 2015.

GARCIA, Leonardo Guimarães; PINHEIRO, Cintia Braga Ferreira. Desenvolvendo a competência em informação das organizações por meio da gestão de pessoas por competências. Encontros Bibli: Revista Eletrônica de Biblioteconomia e Ciência da Informação, Florianópolis, v. 20, n. 43, p. 133-152, 2015. Disponível em: https://periodicos.ufsc.br/index.php/eb/article/download/1518-2924.2015v20n43p133/29964 Acesso em: 6 out. 2015.

GASQUE, Kelley Cristine Gonçalves Dias. Pesquisas na pós-graduação: o uso do pensamento reflexivo no letramento informacional. Ciência da Informação, Brasília, v. 40, n. 1, p. 22-37, jan./abr. 2011. Disponível em: http://www.scielo.br/pdf/ci/v40n1/a02v40n1. Acesso em: 6 out. 2015. 
GOMES, Marcos Aurélio; DUMONT, Lígia Maria Moreira. Possíveis relações entre o uso de fontes de informação e a competência em informação. TransInformação, Campinas, v. 27, n. 2, p. 133-143, maio/ago. 2015. Disponível em: http://periodicos.puccampinas.edu.br/seer/index.php/transinfo/article/view/2924/1962. Acesso em: 6 out. 2015.

HOLLIDAY, Wend et al. An information literacy snapshot: authentic assessment across the curriculum. College \& Research Libraries, Chicago, v. 76, n. 2, p. 170-187, mar. 2015. Disponível em: http://crl.acrl.org/content/early/2014/03/31/crl14-575.full.pdf+html. Acesso em: 6 out. 2015.

INTERNATIONAL FEDERATION OF LIBRARY ASSOCIATIONS AND INSTITUTIONS. Faróis da Sociedade de Informação: Declaração de Alexandria sobre competência informacional e aprendizado ao longo da vida. Versão em português do documento Beacons of the Information Society. Alexandria: IFLA Publicações, 2005. Disponível em: http://archive.ifla.org/III/wsis/BeaconlnfSoc-pt.html. Acesso em: 4 dez. 2015.

KOCHE, Jose Carlos. Fundamentos de metodologia científica: teoria da ciência e prática da pesquisa. 25. ed. Petrópolis: Vozes, 2008.

MANABE, Viviane Magda Marques Luiz et al. Comportamento informacional de ingressantes e concluintes de um curso superior. Encontros Bibli: Revista Eletrônica de Biblioteconomia e Ciência da Informação, Florianópolis, v. 19, n. 40, p. 41-58, mai./ago. 2014. Disponível em: https://periodicos.ufsc.br/index.php/eb/article/view/1518-924.2014v19n41p41/28287.

Acesso em: 6 out. 2015.

MENEZES, Priscila Lopes; VITORINO, Elizete Vieira. A Competência Informacional fundamentada na dimensão ética. Revista da Faculdade de Biblioteconomia e Comunicação da UFRGS, Porto Alegre, v. 20, n. 2, p. 86-107, jul./dez. 2014. Disponível em: http://www.seer.ufrgs.br/index.php/EmQuestao/article/view/46044/32151. Acesso em: 6 out. 2015.

MORAES, Marcos; FURTADO, Renata Lira; TOMAÉL, Maria Inês. Redes de citação: estudo de rede de pesquisadores a partir da competência em informação. Em Questão, Porto Alegre, v. $21, \quad$ n. 2, p. 181-202, mai/ago. 2015. Disponível em: http://seer.ufrgs.br/index.php/EmQuestao/article/viewFile/47481/35085. Acesso em: 6 out. 2015.

MUELLER, Suzana Pinheiro Machado. Produção e financiamento de periódicos científicos de acesso aberto: um estudo na base SciELO. In: PLOBACIÓN, Dinah A.; WITTER, Geraldina Porto; RAMOS, L. M. S. V. C. (Org.). Dos processos tradicionais às perspectivas alternativas da comunicação. São Paulo: Ateliê Editorial, 2011. p. 201-230.

NELSON, Klara; COURIER, Marcy; JOSEPH, Gilbert W. An investigation of digital literacy needs of students. Journal of Information Systems Education, Madison (EUA), v. 22, n. 2, p. 95-109, 2011. Disponível em: http://jise.org/Volume22/22-2/Pdf/Vol22-2\%20pg95.pdf. Acesso em: 6 out. 2015.

NEVES, Bárbara Coelho. Mediação da informação para agentes sociodigitais: o salto. Ciência da Informação, Brasília, v. 40, n. 3, p. 413-424, set./dez. 2011. Disponível em: http://revista.ibict.br/index.php/ciinf/article/view/1954/1438. Acesso em: 6 out. 2015.

ORELO, Eliane Rodrigues Mota; CUNHA, Miriam Figueiredo Vieira da. O bibliotecário e a competência informacional. Informação \& Sociedade: Estudos, João Pessoa, v. 23, n. 2, p. 2532, maio/ago. 2013.2 Disponível em: http://www.ies.ufpb.br/ojs/index.php/ies/article/view/12892/9682. Acesso em: 6 out. 2015. 
ORELO, Eliane Rodrigues Mota; VITORINO, Elizete Vieira. Competência Informacional: um olhar para a dimensão estética. Perspectivas em Ciência da Informação, Belo Horizonte, v. 17, n. 4, p. 41-56, out./dez. 2012. Disponível em: http://www.scielo.br/pdf/pci/v17n4/04.pdf. Acesso em: 6 out. 2015.

PINEDA BÁEZ, Clelia et al. Alfabetización informacional en la educación superior virtual: logros y desafios. Información, Cultura y Sociedad, Buenos Aires, n. 26, p. 83-104, jan./jun. 2012. Disponível em: http://www.scielo.org.ar/pdf/ics/n26/n26a05.pdf. Acesso em: 5 out. 2015.

RASTELI, Alessandro; CAVALCANTE, Lidia Eugenia. A competência em informação e o bibliotecário mediador da leitura em biblioteca pública. Encontros Bibli: Revista Eletrônica de Biblioteconomia e Ciência da Informação, v. 18, n. 36, p. 157-180, jan./abr. 2013. Disponível em: https://periodicos.ufsc.br/index.php/eb/article/view/1518-2924.2013v18n36p157/24518. Acesso em: 6 out. 2015.

RIOS, Terezinha Azerêdo. Compreender e ensinar: por uma docência da melhor qualidade. 8. ed. São Paulo: Cortez, 2010.

ROSMAN, Tom; MAYER, Anne-Kathrin; KRAMPEN, Günter. Intelligence, academic self-concept, and information literacy: the role of adequate perceptions of academic ability in the acquisition of knowledge about information searching. Information Research-An International Electronic Journal, Suécia, v. 20, n. 1, mar. 2015. Disponível em: http://files.eric.ed.gov/fulltext/EJ1060513.pdf. Acesso em: 6 out. 2015.

SANTOS, Antônio Raimundo dos. Metodologia científica: a construção do conhecimento. 3. ed. Rio de Janeiro: DP\&A Editora, 2000.

SANTOS, Camila Araújo dos; CASARIN, Helen Castro Silva. Habilidades informacionais abordadas em instrumentos de avaliação de competência informacional. Informação \& Sociedade: Estudos, João Pessoa, v. 24, n. 3, p. 135-144, set./dez. 2014. Disponível em: http://www.ies.ufpb.br/ojs/index.php/ies/article/view/16501/12408. Acesso em: 6 out. 2015.

SANTOS, Fabiana Pereira; MACHADO, Lucilia Regina de Souza. O papel do bibliotecário de referência na construção do letramento informacional acadêmico: uma prática intersetorial e interdisciplinar. InCID: Revista de Ciência da Informação e Documentação, Ribeirão Preto, v. 5, n. 2, p.142-163, set. 2014/fev. 2015. Disponível em: http://www.revistas.usp.br/incid/article/view/76319/pdf 36. Acesso em: 6 out. 2015.

SANTOS, Mônica Paiva; FREIRE, Gustavo Henrique de Araújo. Formas de aprendizagem no desenvolvimento da competência informacional dos professores associados I do Centro de Tecnologia da UFPB. Perspectivas em Gestão \& Conhecimento, João Pessoa, v. 2, n. especial, p. 40-56, out. 2012. Disponível em: http://periodicos.ufpb.br/ojs/index.php/pgc/article/view/12658/8016. Acesso em: 6 out. 2015.

SCHWEITZER, Fernanda; RODRIGUES, Rosângela Schwarz. Produção científica em áreas multidisciplinares: educação a distância no Brasil. Revista da Faculdade de Biblioteconomia e Comunicação da UFRGS, Porto Alegre, v. 19, n. 1, p. 156-172, jan./jun. 2013. Disponível em: http://seer.ufrgs.br/EmQuestao/article/viewFile/30924/26276. Acesso em: 6 out. 2015.

SERRA, Liliana Giusti. Política para a gestão de livros digitais: a formação do bibliotecário e dos usuários. Brazilian Journal of Information Science: Research Trends, Marília, v. 8, n. 1, p. 1-18, 2014. Disponível em: http://www2.marilia.unesp.br/revistas/index.php/bjis/article/view/ 4253/3092. Acesso em: 6 out. 2015. 
VALENTIM, Marta Lígia Pomim; BITENCOURT JORGE, Carlos Francisco; CERETTA-SORIA, María Gladys. Contribuição da Competência em Informação para os processos de Gestão da Informação e do Conhecimento. Em Questão: Revista da Faculdade de Biblioteconomia e Comunicação da UFRGS, Porto Alegre, v. 20, n. 2, p. 207-231, jul./dez. 2014. Disponível em: http://seer.ufrgs.br/index.php/EmQuestao/article/viewFile/48642/32122. Acesso em: 6 out. 2015.

VARELA, Aida; BARBOSA, Marilene Lobo Abreu. Trajetórias cognitivas subjacentes ao processo de busca e uso da informação: fundamentos e transversalidades. Encontros Bibli: Revista Eletrônica de Biblioteconomia e Ciência da Informação, Florianópolis, v. 17, n. esp.1, p. 142168, 2012. Disponível em: https://periodicos.ufsc.br/index.php/eb/article/view/15182924.2012v17nesp1p142/22730. Acesso em: 6 out. 2015.

VICK, Thais Elaine; NAGANO, Marcelo Seido. A práxis acadêmica de inovação sob a ótica das competências em informação. Informação \& Sociedade: Estudos, João Pessoa, v. 25, n. 2, p. 139-150, maio/ago. 2015.2 Disponível em: http://www.ies.ufpb.br/ojs/index.php/ies/article/view/139/13750. Acesso em: 6 out. 2015.

VICTORELLI, Danielli Santos da Silva. Percepções e perspectivas dos adolescentes sobre a TV digital. RBBD: Revista Brasileira de Biblioteconomia e Documentação, São Paulo, v. 7, n. 1, p. 33-57, jan./jun. 2011. Disponível em: http://rbbd.febab.org.br/rbbd/article/view/182/185. Acesso em: 6 out. 2015.

VIEIRA, David Vernon; BAPTISTA, Sofi a Galvão; CUEVAS CEVERO, Aurora. As competências profissionais do bibliotecário 2.0 no espaço da biblioteca universitária: discussão da prática. Informação \& Sociedade: Estudos, João Pessoa, v. 23, n. 2, p. 45-58, maio/ago. 2013. Disponível em: http://www.ies.ufpb.br/ojs/index.php/ies/article/view/ 15644/9684. Acesso em: 6 out. 2015.

VIRKUS, Sirje. Information literacy in Europe: a literature review. Information Research, v. 8, n. 4, jul. 2003. Disponível em: http://www.informationr.net/ir/8-4/paper159.html. Acesso em: 6 out. 2015.

VITORINO, Elizete Vieira; PIANTOLA, Daniela. Dimensões da Competência Informacional. Ciência da Informação, Brasília, v. 40, n.1, p. 99-110, jan./apr. 2011. Disponível em: http://www.scielo.br/pdf/ci/v40n1/a08v40n1.pdf. Acesso em: 6 out. 2015.

YU, Halida; ABDULLAH, Abrizah; SAAT, Rohaida Mohd. Overcoming time and ethical constraints in the qualitative data collection process: a case of information literacy research. Journal of Librarianship and Information Science, Nova Zelândia, v. 46, n. 3, p. 243-257, 2014. Disponível em: http://lis.sagepub.com/content/46/3/243.full.pdf+html. Acesso em: 6 out. 2015.

Artigo recebido em 11/12/2015 e aceito para publicação em 17/06/2016 